NBER WORKING PAPER SERIES

\title{
MANAGEMENT QUALITY IN PUBLIC EDUCATION: SUPERINTENDENT VALUE-ADDED, STUDENT OUTCOMES AND MECHANISMS
}

\author{
Victor Lavy \\ Adi Boiko \\ Working Paper 24028 \\ http://www.nber.org/papers/w24028 \\ NATIONAL BUREAU OF ECONOMIC RESEARCH \\ 1050 Massachusetts Avenue \\ Cambridge, MA 02138 \\ November 2017
}

We benefited from comments and suggestions by Ema Duccini, Naomi Hausman, Rolant Rathelet, Moshe Shayo, and participants in seminars at the Hebrew University, University of Warwick, University College London, the Madrid January 2017 Education Conference, CESifo Economics of Education Network 2017 Conference, and the 2017 NBER Summer Institute Conference in Personnel Economics. We thank Elior Cohen for providing excellent research assistance during the early stages of this study. The first author acknowledges financial support for this project from the European Research Council through ERC Advance Grant 323439, CAGE at Warwick and the Falk Institute in Jerusalem. The views expressed herein are those of the authors and do not necessarily reflect the views of the National Bureau of Economic Research.

NBER working papers are circulated for discussion and comment purposes. They have not been peer-reviewed or been subject to the review by the NBER Board of Directors that accompanies official NBER publications.

(C) 2017 by Victor Lavy and Adi Boiko. All rights reserved. Short sections of text, not to exceed two paragraphs, may be quoted without explicit permission provided that full credit, including ( $)$ notice, is given to the source. 
Management Quality in Public Education: Superintendent Value-Added, Student Outcomes and Mechanisms

Victor Lavy and Adi Boiko

NBER Working Paper No. 24028

November 2017

JEL No. I0,I21

\begin{abstract}
We present evidence about the ways that school superintendents add value in Israel's primary and middle schools. Superintendents are the CEOs of a cluster of schools with powers to affect the quality of schooling, and we extend the approach used in recent literature to measure teachers' value added, to assess school superintendents. We exploit a quasi-random matching of superintendent and schools, and estimate that superintendent value added has positive and significant effects on primary and middle school students' test scores in math, Hebrew, and English. One standard deviation improvement in superintendent value added increases test scores by about 0.04 of a standard deviation in the test score distribution. The effect doesn't vary with students' socio-economic background, is highly non-linear, increases sharply for superintendents in the highest-quartile of the value added distribution, and is larger for female superintendents. We explore several mechanisms for these effects and find that superintendents with higher value added are associated with more focused school priorities and more clearly defined working procedures, but no effect on school resources and no effect on total teachers' on the job and external training, although there is a significant effect on the composition of the former. Another important effect is that schools with higher quality superintendents are more likely to address school climate, violence and bullying, and implement related interventions which lead to lower violence in school. A new superintendent is also associated with a higher likelihood that the school principal is replaced.
\end{abstract}

Victor Lavy

Department of Economics

University of Warwick

Coventry, CV4 7AL

United Kingdom

and Hebrew University of Jerusalem

and also NBER

v.lavy@warwick.ac.uk

Adi Boiko

Department of Economics

Hebrew University

Mount Scopus Jerusalem Israel

adi.boiko@mail.huji.ac.il 


\section{Introduction}

Recent studies examined the relationship between management quality and productivity in the public sector. Di Liberto (2013), Bloom et al. (2015) and Bryson et al. (2017) have extended the World Management Survey methodology to measure management practices in schools, and present descriptive evidence about the quality of management by school principals and education outcomes in several countries. They show that better quality management is strongly associated with better educational outcomes, but they cannot establish causality in this relationship. Branch et al. (2012) study school principals' leadership roles and measure the correlation with school outcomes. Bloom, Propper et al. (2015), McCormack et al. (2013), and Rasul and Rogger (2013) study management practices in public sector institutions and other government agencies. In this paper we focus on measuring the effect of superintendents in public education on the education outcomes of students and schools and the channels of these effects. ${ }^{1}$ School superintendents are the CEOs of a cluster of schools within a school district or a local school authority. In Israel, as in many other countries, these CEOs have wide responsibilities that affect school quality and output. For example, they are the direct managers of school principals and draw their authority from the district or regional education director. In recent years this model of superintendent as school CEO has been criticized as inefficient, too procedural, anachronistic and not innovative, and insignificant in its impact on the quality of schools. Many countries have reacted to this perceived inefficiency with extensive management reform in public education. ${ }^{2}$

However, the link between management quality and the effectiveness/productivity of schools has not been studied as carefully as, for example, the impact of teachers' value added (Rivkin et al 2005, Rothstein 2010, Jacob et al 2010, 2016, Chetty et al 2014a, 2014b). This paper provides empirical evidence about the causal effect of management quality in public education on students' cognitive and non-cognitive schooling outcomes and explores some of the relevant mechanisms. We measure superintendent quality by their value added in terms of students' test scores, and in a second step we estimate the effect on students' schools cognitive and behavioural outcomes.

The role and responsibilities of superintendents vary across countries but it is common for them to set the tone, chart the course of the district or sub-district, and work closely with the school board or

\footnotetext{
${ }^{1}$ Superintendent is the title used in the US and in some other countries. In the UK the title used is Chief Education Officer, in Canada it is Director of Education.

${ }^{2}$ For example, England, New Zealand, Finland and Chile introduced global transformation in the organization and regulation of their education system and in the role of supervision of schools (UNESCO 2007). In some countries profound structural changes have been introduced, for example, changing school structures (charter schools in the US and school academies in the UK), accountability measures (performance league tables and closure of failing schools as in the US No Child Left Behind), and programs that enhance school competition (voucher programs, free school choice, financial incentives to staff and students). Only few of these programs were expanded at scale, partly because of their lack of popularity among educational practitioners, who believe that the current system of management and supervision in public education maintains proper motivation and quality in schools.
} 
district board of trustees. Superintendents are responsible for hiring and supervising school principals and teachers, including the decision to grant tenure to novice teachers. It is the superintendent's job to evaluate school principals' performances and ensure that they are effective leaders, working with teachers to serve the needs of students and meet the district goals. The superintendent must respond to demands from all other constituencies in the district or sub-district: the teachers, students, parents, and the community at large. In some countries, superintendents can affect the allocation of financial and human resources in the district. Therefore a high quality superintendent can have an important effect on the quality of a school and on students' academic achievements.

Non-random matching of schools and superintendent can lead to biased measures of superintendents' value added. We address this concern by exploiting a quasi-random pairing of superintendents and schools that results from a Ministry of Education rule, under which the superintendents' 'supervision area' must change every 3-5 years, leading to schools being reshuffled across superintendents' clusters. The implementation of this regulation is closely linked to superintendents' retirement and sometimes, though not very often, to promotion of superintendents within the Ministry of Education. Such exits lead to new superintendents entering and to some reshuffling of schools across existing superintendents. Most often, the whole cluster of schools of a retiring superintendent is transferred as a group to a different superintendent. Clearly there should be no concern for sorting in such cases and we show evidence that supports our claim of random matching of schools and superintendents. We show that the probability of having a superintendent change is unrelated to school characteristics and outcomes. We show that a new superintendent's quality is unrelated to school characteristics and outcomes. We also show that the quality of the new and old school's superintendents are not correlated.

We estimate superintendents' value added in two different ways. In the first, we measure superintendents' value added based on schools that did not switch superintendent during the study period. The value added is measured as a superintendent fixed effect in a regression of a school level education production function. In a second step we estimate the effect of superintendent value added on outcomes of schools that switched to a new superintendent. As an alternative approach we exploit superintendent turnover and measure value added based on schools that switched superintendent. Value added here is measured by a superintendent fixed effect in a regression of the change in cognitive outcomes. In a second step we estimate the effect of superintendent value added based on the sample of schools that did not switch superintendent.

The ranking of superintendents obtained from these two methods are highly positively correlated and the estimated effect of these two alternative superintendents' value added measures on students' test scores are very similar. For learning outcomes we use test scores in national exams in primary and middle schools in Israel in math, Hebrew, and English. We also examine effects on students' behavioural outcomes, in particular measures of bullying and violence in school and students' 
social skills and behavior. As potential mechanisms for the effect of superintendent quality we focus on several management practices of school principals.

The results show that the quality of superintendents has positive and significant effects on students' academic achievements. A one standard deviation improvement in management-supervision quality increases students' test scores in math, English and Hebrew by 0.04 standard deviation. These positive within-school estimates contrast with the "naïve" OLS estimates which are actually negative, reflecting a negative selection pattern in the sorting of superintendents to schools. The effect is nonlinear, being higher for the highest quality superintendents. The treatment effect is on the same scale when estimation is by subject. Interestingly, female superintendents have higher value added and higher impact on students' outcomes.

This paper also contributes to several literatures. First, we link to work on teachers' value added and its effect on students' academic achievement (Rockoff 2004, Rivkin et al (2005), Jacob (2010), Rothstein (2010), Bacher-Hicks, Kane, and Staiger (2014), and Chetty et al. (2014)). Secondly, this paper is related to recent research on the effect of school principals and leadership (for examples see Branch, Hanushek, and Rivkin (2012), Clark, Martorell, and Rockoff (2009), Béteille, Kalogrides, and Loeb (2012), and Horng, Klasik, and Loeb (2010)). Finally and more generally, we contribute to the emerging literature investigating management practices in public sector institutions (For examples see McCormack, Propper, and Smith (2013), Rasul and Rogger (2013), and Bloom, Propper, Seiler and Van Reenen (2015)).

The rest of the paper is organized as follows. Section 2 presents background on the system of superintendents in Israel and elsewhere. Section 3 presents the data and section 4 presents our empirical strategy and results on the effect on students' outcomes. Section 5 presents evidence on the mechanisms of the effect of managerial and supervision quality and section 6 presents the conclusions.

\section{Context and Background}

There are school supervision services in nearly all countries. ${ }^{3}$ Their key role is to monitor the quality of education, i.e. schools and teachers, and support their improvement, creating two distinct but complementary tasks: on the one hand, to control and evaluate and, on the other hand, to advise and support teachers and head-teachers. Superintendents (in some countries they are called supervisors) are based outside the school at a local or regional government body overseeing public schools. Each superintendent is assigned a number of schools, to which they make regular visits every year. The role and powers of the superintendent vary considerably between countries, however, their tasks generally include: supervising implementation of government education policy, regulations, and national curriculum, advising on teaching methods, supervising, guiding and assessing teachers on probation,

\footnotetext{
${ }^{3}$ Much of the material in this section is based on "Reforming School Supervision for Quality Improvement", United Nations, International Institute for Educational Planning, UNESCO 2007.
} 
liaising with and advising headmasters, guiding schools in responding to patterns of problems and needs, and reporting on periodic inspections. Some countries, for example Spain, separate the administrative from the pedagogic tasks of supervisors. Other countries tend to separate control and support roles. This has been the case mainly in countries with strong school-based management practices such as New Zealand and the UK. Some countries adopted a management-supervision approach directed towards the school as a whole and less on individual teachers. A noticeable example is the OSTED school audit system in the UK. In France, superintendents produce regular reports on issues based on specific fieldwork and special school visits. In few countries, schools use selfassessment instead of external supervision. Finland follows this model, and quality control is entirely entrusted to teachers. Other countries use a model that combines internal school evaluation and assessment with external supervision (New Zealand, Wales, Australia, and Chile).

School superintendents in Israel are Ministry of Education staff. While a school principal is responsible for the day-to-day administration of school, the school superintendent has a diverse range of activities and responsibilities, both at the macro and micro level. At the 'macro' level he oversees the development of each school's annual strategic action plan in line with its school charter, which sets out the educational objectives for the school under the national curriculum framework. The superintendent also oversees implementation of the action plan, and is responsible for decisions about hiring, placement and transfer of teachers. At the 'micro' level, he assesses teachers' performance, provides pedagogic guidance and know-how to school principals and teachers, decides about tenure and dismissal of teachers, and deals with students' extreme disciplinary violations, including the approval of temporary or permanent expulsion of students. To carry out these tasks, the superintendent visits every school a few times a year, meets with the school principal and members of the school senior leadership team, attends classes, mainly of novice teachers, and holds confidential meetings with teachers and staff. He is expected to develop a safe and trusting relationship with his supervisees and use these meetings to talk about all elements of their practice, including emotional and psychological difficulties at work. It is the superintendent's responsibility to encourage teachers and school principals to improve their classroom instruction, and ensure that they work within the norm, policies, and codes of practice of the Ministry of Education and the law. The superintendent should monitor training and teaching progress and ensure that novice teachers receive appropriate career guidance. Following each school visit, the superintendent should submit a report to the school district director. Supervisees should receive relevant parts of the report and be able to comment on their assessment and on the support provided, and to discuss any problems that were identified.

The majority of school superintendents in Israel adopt a hierarchical approach, conducting their interaction with teachers and school principals as an educational authority, and the school staff view them as the highest pedagogical authority. In accordance with the State Education Law, the Ministry of Education is the superintendents' employer, navigate and guide them in their work. Most 
superintendents in their daily work are part of the staff of regional directors (there are seven regions in the country). Each superintendent is in charge of a number of schools. Every 3 to 5 years superintendents rotate to a different "supervision zone", or there is a broad reallocation of schools they supervise.

\section{Data}

The data we use in this study are based on the Growth and Effectiveness Measures for Schools (GEMS - Meizav in Hebrew) datasets for the years 2002-2005. The GEMS was administered for the first time in 2002 and it includes a series of tests and questionnaires administered by the Division of Evaluation and Measurement of the Ministry of Education. ${ }^{4}$ The GEMS is administered towards the end (from midMay to mid-June) of each school year to a representative 1-in-2 sample of all elementary and middle schools in Israel, so that each school participates in GEMS once every two years. The GEMS data include test scores of fifth- (primary school) and eighth- (middle school) grade students in math, science, Hebrew, and English. In principle, all students except those in special education classes are tested and the proportion of students tested is above 90 percent. The raw test scores used a 1-to-100 scale that we transform into z-scores to facilitate interpretation of the results. In this study we use only primary school data since the funding reform only affected primary level schools.

The test scores for the years 2002-2005 are linked to student administrative records collected by the Ministry of Education. The administrative records include student demographics, which we use to construct all measures of students' background characteristics. Using the linked datasets, we build a panel for elementary schools with test scores for the years 2002-2005. The sample is restricted to Jewish public schools that follow the same national curriculum and participate in the GEMS national testing. For these reasons we exclude the religious Orthodox Jewish schools and the Arab schools. There are 939 elementary schools with test score data. Since every school is sampled once in two years, we have two observations of the same school for more than 90 percent of the schools.

The GEMS also includes interviews with all teachers and the school principal. The questionnaire for 'home class' teachers ${ }^{5}$ of all classes included questions about instruction time in each subject and the total instruction time per week. We use teachers' responses to these items to compute the school average for fifth-grade instruction time in each subject. Though there was very little difference between or among fifth-grade classes in a school in these time inputs, we still prefer to use the school-level mean per grade to avoid any biases that might be caused by sorting of students into

\footnotetext{
${ }^{4}$ The GEMS is not administered for school accountability purposes and only aggregated results at the district level are published. For more information on the GEMS see the Division of Evaluation and Measurement website (in Hebrew): http://cms.education.gov.il/educationcms/units/rama/odotrama/odot.htm.

${ }^{5}$ A 'home class' teacher in primary school in Israel teaches most weekly sessions of his class, and has additional duties such as taking attendance registers, acting as intermediary in cases of conflict, collating other teachers' impressions of the class and of individual students in preparation for the quarterly report, liaising with parents and various other administrative tasks.
} 
certain classrooms and setting time allocations for given academic subjects according to those students' particular strengths and weaknesses. In any case, the grade- and class-level measures of these time inputs are very highly correlated.

The school principal questionnaire includes questions on pedagogical and management practices in school. We use the following questions: (1) "Did the school evaluate its environment and discipline?" and (2) "Does the school have interventions related to values, norms and discipline?".

We also use items from the GEMS student questionnaire that address various aspects of the school and their learning environment. We concentrate on the section of the questionnaire that provides information on student satisfaction in school and on the violent behaviour of other students. In this section students are asked to rate the extent to which they agree with a series of statements on a sixpoint scale ranging from "strongly disagree" to "strongly agree". These items include: (1) "There are many fights among students in my classroom"; (2) "Sometimes I'm scared to go to school because there are violent students"; (3) "This year I was involved in many fights"”; (4) “"When I have a problem at school there is always someone I can turn to (from the teaching staff)"; (5) "I am satisfied in school"; and (6) "I feel well-adjusted socially in my class". We transformed students' responses to these items into standardized z-scores. ${ }^{6}$

\section{The Quasi-Random Pairing of Schools and Superintendents}

The pairing of schools and superintendents may be non-random. For example, school authorities may place more proven and effective superintendents in weaker or failing schools, or experienced superintendents may prefer to work in better schools. Therefore, the potential endogenous sorting of superintendents in schools has to be accounted for when measuring unbiased superintendents' value added. The administrative structure of superintendents in Israel and the schools they manage offers a way to measure superintendents' value added that is not affected by endogenous sorting of superintendents. Israel's public education system has seven geographical regions, each headed by a regional director that reports directly to the general director of the Ministry of Education. All schools within each of the seven regions are under the directorate of the regional director. Each region has several superintendents and each is in charge of a number of schools. Except for the large cities (Jerusalem, Tel Aviv, Haifa, Beer-Sheba, Rishon-Lezion), all other localities have only one superintendent who supervises all schools in the locality. Each such superintendent will manage few localities that are close geographically. This is clearly evident from the information presented in Maps 1-6. Each map presents the geographical distribution of the schools by superintendent in each of the

\footnotetext{
${ }^{6}$ We experimented with binary versions of these variables denoting above median answers and also using them linearly and the results were not different, confirming that the evidence regarding these variables is not a feature of this particular transformation of the data.
} 
seven regions in 2005. The spatial clustering of the schools of each superintendent clearly suggests matching of schools and superintendents are based on geographic considerations. About 77 percent of schools in our sample are in municipalities with a single superintendent and about 82 percent of these schools have a superintendent who oversees schools in more than one municipality. Every change of a superintendent in these municipalities involves all schools, minimizing in this context the scope for selective matching between superintendents and schools.

The large cities noted above have more than one superintendent: the first three have 3 superintendents and the other two cities have 2. The distribution of schools of each superintendent in these large cities is also clustered geographically, shown in Maps 1-6. The schools that are included in each superintendent cluster are mostly the same over time, particularly when there is a change of superintendent.

The Ministry of Education reassigns superintendents every 3-5 years. ${ }^{7}$ This is often implemented in conjunction with the departures of superintendents due to retirement - rarely due to promotion. Our panel data for the period 2002-2005 includes 771 schools that appear in the sample each of the four years. There are three potential transition points, one for every two adjacent years and 402 schools (52\%) switched superintendent at least once within this period. This transition rate implies that a school will indeed have a new superintendent every 5-6 years. Very often, the whole cluster of schools of a retiring superintendent is transferred as a group to a novice or veteran superintendent. Fifteen percent of the changes in the pairing of schools and superintendents results from such reassignment and an additional 61 percent of the transitions result from a transfer of at least 5 schools from a retired or promoted superintendent to different superintendent. Clearly when the reassignment involves such large number of schools as in these cases, we can confidently rule out any endogenous sorting that might lead to selection bias in the measure of superintendent value added an in the treatment effects estimates. The reassignment of one or two schools to a new or veteran superintendent accounts for only 9 percent of all reassigned schools (40 out of 459). The reassignment of three or more schools to a new or veteran superintendent accounts for 91 percent of all reassigned schools. In fact, out of the 40 schools reassigned as a single or a couple of schools in the reassigned cluster, the reassignments of 25 schools seem to be driven by spatial reasons, as the reassigned schools are geographically closer to the receiving superintendent's cluster of schools. Clearly there should be little concern for endogenous sorting in these transitions.

Some evidence for the lack of endogenous sorting of superintendents can be seen in Figures 13 which are representative examples of patterns of turnover of superintendents following a retirement of one or more superintendents. Figure 1 presents the changes in the Central educational district

\footnotetext{
${ }^{7}$ https://he.wikipedia.org/wiki/\%D7\%9E\%D7\%A4\%D7\%A7\%D7\%97_(\%D7\%97\%D7\%99\%D7\%A0\%D7\%95 $\% \mathrm{D} 7 \% 9 \mathrm{~A})$.
} 
following the retirement of two superintendents. All of Ruth's (this and other names in the paper are fictitious) schools were transferred to Rebecca (a new superintendent) and all of Amalia's schools were transferred to Hannah (a veteran superintendent). Rebecca received also ten schools from Johanna. The transfer in bloc of such large number of schools between pairs of superintendents clearly suggests that there was no sorting involved. However, Figure 1 show transfers of smaller numbers of schools between superintendents, in most cases 1 or 2 schools, which may involve sorting. In Figure 2 Judith, a superintendent in South district, retired and her 13 schools were distributed between 4 other superintendents. Figure 3 shows transitions in the Haifa district in 2003-2004. There are 8 pairwise transfers, five of them involving a move 5 or 6 schools. In most cases the number of outgoing and incoming schools of a superintendent are equal or almost equal.

\section{Measuring Superintendents' Value Added}

We estimate superintendents' value added in two different ways. In the first method (I), using the sample of schools that did not change their superintendent during the study period ('the nonswitchers') we estimate an education production function with a superintendents' fixed effect and use these fixed effects as measures of superintendents' value added. In a second step we estimate the effect of these superintendents' value added on outcomes of schools that did change their superintendents (the 'switchers'). Using two different samples in the two steps of this procedure guarantees that the superintendent fixed effect does not reflect specific characteristics of the schools that are included in the sample in the second step. This 'out of sample' procedure of estimating the superintendent fixed effect is crucial even though we estimate the role of CEOs of education districts in a framework where we can control for observable and unobservable differences across schools. For this purpose, we construct a superintendent-school matched panel data set, where we track superintendents across different schools over time. This allows us to estimate how much of the unexplained variation in schools' average outcomes can be attributed to superintendent value added (fixed effects), after controlling for schools' fixed effects and time-varying school characteristics. The second method (II) reverses the role of 'switchers' and 'non-switchers': We exploit superintendents' turnover, using schools that were assigned a new superintendent ('switchers') and measure value added as the superintendent 'fixed effect' in a regression of the change in schools' mean test scores as a dependent variable. In a second step, we estimate the effect of the value added of these superintendents on mean test scores of the sample of the 'non-switchers', the schools that were not assigned a new superintendent. Both methods rely on the assumption that schools that are part of a superintendent's cluster of schools, do not share any other common factors that can correlate with their residual test scores (method I) or their residual growth in test scores (method II). Both methods are similar in spirit to the models that are used to estimate the effect of individual managers on corporate behavior and performance (Bertand and Schohar 2003). 
We show below that the percentile ranking of superintendents' value added derived from these alternative methods are highly correlated. We also show that the two series of value added, based on the second method (one for each year) are also highly correlated. Finally we will observe that the estimated treatment effects obtained from value added I and value added II are very similar.

We specify an education production function that includes an input that captures superintendent quality or value added in addition to the standard school and student level inputs:

$$
Y_{j s}=\alpha_{j}+\gamma O_{s}+\beta X_{j}+\Lambda L A_{j}+u_{j s}
$$

where $Y_{j s}$ is the average learning outcome of students in school $j$ that is assigned to superintendent $s$. We use test scores in national exams in primary $\left(5^{\text {th }}\right.$ grade $)$ and middle school $\left(8^{\text {th }}\right.$ grade $)$ in Israel in math, Hebrew, and English as measures of learning outcomes. We also examine effects on students' behavioural outcomes, in particular measures of bullying and violence in school and students' social skills and behavior. As potential mechanisms for the effect of superintendents' quality we focus on several management practices of school principals. $\alpha_{j}$ is a school fixed effect, $O_{s}$ captures the value added of superintendent $s, X_{j}$ is a set of potentially time varying covariates of school $j$ (including students' characteristics, school enrolment, number of classes), $L A_{j}$ is a vector of lagged test scores in Hebrew and math and $u_{j s}$ is a mean zero residual.

The parameter of interest is $\gamma$ but $O_{s}$ is unobserved and therefore has to be estimated. Since superintendent value-added might be measured with error, it can be correlated with $u_{j s}$ and therefore with school specific outcomes shocks which are part of the error term in equation (1). To avoid this problem we use the same approach as in recent studies of teachers' value added, for example Jacob et al (2010), where estimation of the value-added of a student's teacher does not incorporate information from that student's cohort. In our case, this approach implies that the estimation of the value-added of a school's superintendent does not incorporate information from that school. Stated differently, the value added of a school's superintendent is estimated out of sample for every school for every period. Stated explicitly, in the first method we measure value added based on 'non-switchers' and in a second step estimate its effect using the sample of 'switchers'. In the second method we measure value added based on 'switchers' and in a second step estimate its effect using the sample of 'non-switchers'.

\section{Method I: Measuring Superintendents Value Added Based on 'Non-Switchers'}

Based on the non-switchers' sample (schools that stayed with the same superintendent during the study period), we estimate equation (1) while including a dummy variable for each superintendent. The practical representation of this specification is that a vector of superintendents' fixed effects is included in equation (1) and the estimates of these fixed effects are the measure of superintendents' 
value added. ${ }^{8}$ We estimate this regression separately for each of the sub-periods: 2002-03 and 2004-05. Each school is included once in each of these regressions because the test scores data is available for each school in one of the two years of each of these two periods. Here as well, the interpretation of the superintendent fixed effect as a value added measure rests on the assumption that all schools that share the same superintendent do not share any other common factor that might affect their learning outcomes. Including many students' and school level controls in equation (1), in particular lagged school level means test scores, as done in the above-referenced studies on teachers' value added, ensures that the superintendents' fixed effects picks up only the superintendent's value added.

Table 2 presents the estimates of these two regressions from which we recover the estimated superintendents' fixed effects. The $X_{j}$ vector includes an indicator for male students, number of siblings, an immigrant indicator, father's and mother's years of schooling, six indicators of student's ethnicity, school enrolment and number of classes. The means and standard deviations for these variables are presented in columns 1 and 3 for each of the two periods. ${ }^{9}$ The 1991 schools standardized test scores means of $4^{\text {th }}$ and $5^{\text {th }}$ grade in Hebrew and math are also included in these regressions. The point estimates of the control variables have the expected signs: boys have 0.10- 0.13 standard deviation lower test scores than girls, number of siblings is negatively correlated with test scores, immigrants and students from Asia-Africa and Ethiopian ethnic background have negative correlation with test scores, and parental schooling and ethnicity from Europe, America, Israel and the former Soviet Union has positive correlation with test scores. The school average lagged test score in Hebrew has a significant positive effect on current outcomes but the estimate of the lagged math test score is zero. These estimates are much weaker, because the school test score means are highly correlated with the school means of students' characteristics that are also included in these regressions.

We standardized the superintendents' fixed effects as a z-scores distribution with mean zero and standard deviation one. Figure 6 displays the two distributions (first and second period) of the standardized value added measure of 47 superintendents that are in charge of 497 schools. The two distributions look identical, and their equality is not rejected in a two-sample KS test. The correlation coefficient between these two value-added measures of each superintendent is 0.62 .

The use of lagged scores as controls is meant to ensure that the superintendent fixed effect does not capture some unobserved school-specific characteristics. Although short lags would be ideal to do

\footnotetext{
${ }^{8}$ This approach is identical to the method used in Rivkin et al (2005) and Jacob (2010) who measured teachers' value added and also very similar to the method used in Rothstein (2010) and Chetty et al. (2014) in a teachers' value added context as well.

${ }^{9}$ It is important to note that these student and school's characteristics are the main determinant of school government funding. In 2002 and 2003 the school budget was mainly a function of number of classes in school and on a school level deprivation index (which was function of a school's mean of student characteristics). In 2004 and 2005 school funding was based on school enrolment and the school deprivation index. See Lavy (2017) for more details on the funding rules in the two periods.
} 
so, the 1991 scores which are available to us perform just as well. Figure 7 displays the distributions of student-level estimated standardized value added of the 2004-2005 period using alternative lagged scores sets as controls. The distribution of value added using the 1991 lagged scores as controls and the value added distributions using 2002-2003 lagged scores look identical, and equality of any distribution pair cannot be rejected by a two-sample KS test. This provides important support to the validity of our value added estimates.

\section{Method II: Measuring Superintendents'Value Added Based on Switchers}

We specify a school level value added regression:

$$
Y_{j 1}-Y_{j 0}=\gamma O_{s j l}+\beta\left(X_{j 1}-X_{j 0}\right)+\delta\left(S_{j 1}-S_{j 0}\right)+\mu Y_{j l}+u_{j 1}
$$

when the dependent variable is the change in test score between period 0 and period 1 . $\hat{O}_{j s l}$ is the new superintendent $j$ in period 1 of school s. $X_{j 0}$ and $S_{j 0}$ are the students' and school's mean characteristics in the first period and $X_{j l}$ and $S_{j l}$ are the respective means in the second period. $\left(X_{j 1}-X_{j 0}\right)$ and $\left(S_{j l}-S_{j 0}\right)$ are the changes in students' and school's characteristics. Superintendent fixed effect $O_{j}$ is the mean residual change in test scores (value added) of the schools that are part of the cluster of superintendent j. $Y_{j l}$ is the lagged test scores in math, English and Hebrew. As lagged test scores we use the earliest test scores data available for all schools from a national testing program in 1991 and 1992. The 1991 data include test scores in Hebrew and math in $4^{\text {th }}$ and $5^{\text {th }}$ grade and the 1992 data include test scores of 3rd graders in the same subjects. Even though these data are from more than a decade ago, they are strong and precise predictors of the 2002-2005 test scores. For example, the $\mathrm{R}^{2}$ of a regression of the 20022003 stacked test score in Hebrew and math on the 2004-05 respective test scores is 0.42 . The $\mathrm{R}^{2}$ when the 1991 test scores replace the 2002-2003 scores is 0.41. Furthermore, when the 1991 test scores are included jointly with the 2002-2003 test scores in a regression of the 2004-05 test scores, both lagged sets of test scores have positive and similar coefficients. ${ }^{10}$

We combine all observed data throughout the study period, 2002-2005, for the estimation of superintendent's value added. Table 3 presents the estimates of equation (2). The $X_{j}$ vector includes an indicator for male students, number of siblings, an immigrant indicator, father's and mother's years of schooling, six student's ethnicity indicators, school enrolment and number of classes. The means and standard deviations for these variables are presented in column 1 of Table $3 .{ }^{11}$ Most of the estimated coefficients of the right-hand side variables are different from zero except for the two parental education variables. This pattern is most likely a result of the stability of the characteristics of a school within this

\footnotetext{
${ }^{10} \mathrm{We}$ don't present these results in the paper and they are available from the authors upon request.

${ }^{11}$ It is important to note that these student and school's characteristics are the main determinant of school government funding. In 2002 and 2003 the school budget was mainly a function of number of classes in school and on a school level deprivation index (which was function of a school's mean of student characteristics). In 2004 and 2005 school funding was based on school enrolment and the school deprivation index. See Lavy (2017) for more details on the funding rules in the two periods - a reference is missing.
} 
short period. From this regression we recover the superintendents' fixed effects. These are then standardized as a z-scores distribution with mean zero and standard deviation one. Figure 8 displays the distribution of the standardized value added measure of 44 superintendents that are in charge of 226 schools. ${ }^{12}$ It is clear that there is large variation in superintendent quality which we can use to estimate its impact on schools' academic and non-academic outcomes.

The correlation coefficient between the two measures of superintendent value added, based on the sample that includes all superintendents for which we computed value added I and II, is 0.61 . It is very re-assuring that these two alternative measures, based on very different methods and samples, are highly correlated.

Are Switching Schools and Superintendents Quasi-Randomly Matched? In this section we show that the likelihood that a school experienced a change in superintendent is unrelated to the superintendent's value added or to the school characteristics. This is an expected result, given the details in section 2 clarifying that changes in superintendent-school paring are related to personal and geographical considerations, and not to the relationship between the school and the quality of its superintendent.

Are schools that changed or remained with the same superintendent observationally equivalent? In Table 4, we present summary statistics for the variables used in the analysis. Column 1 presents the means for the sample of all schools that did not change superintendent during the period of the study, and column 2 presents the respective means for the schools that did change superintendent during this period. Panel A includes 13 schools' mean of its students and other characteristics (gender, number of siblings, immigrant status, mother and father years of education, and 6 ethnic origin indicators, enrolment and number of classes). Panel B includes schools' mean of its students' test scores in national standardized exams in math, Hebrew and English. The 497 schools that stayed with the same superintendent during the study period had 63,979 students and 47 superintendents. The 82 schools that switched superintendent between 2002 and 2004 or between 2003 and 2005 had 10,293 students and 29 superintendents.

In column 3 we present the balancing tests between columns 1 and 2 , which are a test of a correlation between the probability of a school changing superintendent and its observable characteristics. There are 16 parameter estimates and only one of them is statistically different from zero. With respect to the proportion of Asia-Africa ethnicity, the difference is larger and more significant. However, it should be noted that the two groups are statistically indistinguishable in terms of their parental years of schooling and in terms of the average test scores in each of the three subjects, both in terms of the absolute differences and their statistical significance. We view this evidence as

\footnotetext{
${ }^{12} \mathrm{We}$ also estimated the value added regression where school means data replaces student-individual in outcome test scores and student characteristics. The distribution of the superintendents' value added values looks identical to that displayed in Figure 2.
} 
suggestive of no particular pattern of selection in the probability of changing superintendent, and definitely no correlation with students' socio-economic background and test scores.

Next we estimate whether quality of the incoming superintendent is correlated with observable school characteristics and outcomes. We use the value added based on method I and method II. These balancing tests are presented in columns 4-5 of Table 4. In column 4 we present the estimates based on value added I. The sample includes only the 82 schools (10,249 students and 29 superintendents) that switched superintendent between 2002 and 2004 or between 2003 and 2005. Four of the 16 estimates in column 4 are statistically different from zero: ethnicity Israel and ethnicity Europe-America are positively and negatively correlated, respectively, with superintendent quality. These two ethnic groups have higher socio-economic backgrounds than the other ethnic groups so we expect that they will have the same direction of selection. But we see that these two ethnic indicators have the opposite sign of their correlation with superintendent value added, one positive and the other negative, suggesting perhaps that their significance imbalance does not reflect a systematic selection pattern in the assignment of schools to superintendents. The evidence is a clear indication that overall this value added measure is not systematically correlated with students' and schools' observed background variables. Particularly reassuring is the lack of any correlation with student's parental education and with lagged test scores in panel B. Another point that underscores the relatively marginal importance of these imbalances is that our model of estimating the effect of value added I on school outcomes includes a school fixed effect that is feasible because we observe each school with two different superintendents. In column 5, we present estimates based on value added II. The sample includes 301 schools that did not change superintendent. Only one of the 16 estimates is statistically different from zero, ethnicity Ethiopian.

\section{Estimated Impact of Superintendents' Value Added}

We estimate equation (1) twice, first using school level means for all variables and secondly with student level data. Using student micro data of course allows estimation with much larger sample, leading to more precise estimates. It also allows estimation of treatment heterogeneity by students' characteristics: particularly important in this context is the heterogeneity of the effect of superintendent value added by students' socio-economic background.

The first row of Table 6 presents estimations with school level data of the effect of superintendent value added on students' achievement in math, English, and Hebrew. In columns 1-4 we present the estimates of the effect of value added based on the first measure. Here we use the sample of 'switchers', schools that changed superintendent between two periods. These schools will have a different superintendent in each period and so their superintendent $\hat{O}_{j s t}$ value added will be period $(t)$ specific. The GEMS data provides panel data on schools where each school participates in two rounds of national testing, between which it experiences a change in its superintendent. Schools that participate in the 2002 testing round are also included in 2004. Similarly, schools included in the 2003 testing are 
also included in 2005. We stack this panel data so that $\alpha_{j}$ can be estimated as a school fixed effect. The advantage of this school fixed effect model (which is equivalent to a difference equation at the school level) is that it controls for omitted time-invariant variables biases that could potentially be correlated to superintendents' value added. We report results from four different specifications. In column 1 the regression includes year effect as a control; in column 2 subject fixed effects are added as a control; in column 3 schools' and mean students' characteristics are added as well, and in the fourth specification, reported in column 4, we also include school fixed effects. The estimates in columns 1-3 are negative but small and not significantly different from zero. The within school estimate (regressions with schools fixed effect) presented in column 4 is, however, positive, 0.038 , and significantly different from zero at the 5 percent level of significance, suggesting that one standard deviation increase in superintendent value added increases test scores in the three subjects by 3.8 percent of a standard deviation of the test score distribution. In the second row of Table 6 we present the estimates based on the students' sample. Standard errors are therefore clustered at the superintendent level by year level. The estimates in this row are similar to those presented in the first row. The respective estimate in this sample is 0.040 $(\mathrm{se}=0.015) .{ }^{13}$

In columns 5-7 we report results based on the second value added measure from three different specifications, identical to those in columns 1-3. The unit of observation is the student, but the level of treatment is at the school level. The estimates in columns 5-7 are positive but only the estimate in column 7, 0.061, is significantly different from zero at the 5 percent level of significance. Since both the superintendent value added and the test scores are standardized to mean zero and a unit standard deviation, this estimated effect implies that one standard deviation increase in superintendent value added increases test scores in the three subjects by 6.1 percent of a standard deviation of the test score distribution. The respective estimate using student level data is 0.053 and it is only significant at the 10 percent level of significance. This effect implies that one standard deviation increase in superintendent value added increases test scores in the three subjects by 5.3 percent of a standard deviation in the test score distribution.

Remarkably, the two measures of superintendent value added yield similar estimated effect sizes, especially when comparing the estimates using the micro students' data: 0.053 versus 0.040 . Both are statistically different from zero but their confidence intervals overlap.

As a robustness check of our results, we also estimated the effect of the superintendent's quality measure using two alternative estimation strategies. In the first strategy we implement a Bayes shrinkage estimation strategy and construct an unbiased measure of superintendent value added that

\footnotetext{
${ }^{13}$ These results are robust to the exclusion of the 15 schools that were reassigned as a single-school or two-schools cluster and their reassignment shows no clear spatial logic as discussed in section 4 (See Table A1.) In fact, results are also robust to the exclusion of all the 40 schools that were reassigned as a single-school or two-schools cluster, regardless of spatial distribution (See Table A2.)
} 
accounts for noise in the measurement. Using this approach, the noisy measure of a superintendent value added is multiplied by an estimate of its reliability, where the reliability of a noisy measure is the ratio of signal variance to signal variance plus noise variance. Thus, less reliable measures are shrunk back toward the mean of the distribution of the superintendent value added measure. ${ }^{14}$ In the second strategy we use a two-step bootstrapping algorithm to account for the estimation of superintendents' value added as a first step, and adjust their estimated standard errors. ${ }^{15}$

In both of these alternative estimation strategies we use both measures of value added based on method I and II and we focus on the specification that includes school fixed effects. The results are presented in Table 7. The two alternative estimation strategies yield similar results to the respective estimates presented in Table 6 . The standard errors of the bootstrapping algorithm are almost identical to those of the preferred specification, and accounting for the fact that empirical Bayes estimates are smaller in absolute values than the initial estimates because of the shrinkage procedure (before standardization, the pre-shrinkage mean value of superintendent value added is -0.17 while its postshrinkage value is 0.013), we compare the elasticities of superintendent value added effects at their mean values which yields comparable outcomes.

It is useful to benchmark the effect sizes presented in columns 4 and 7 of Table 6 against the effect of teachers' value added. For example, the findings of Rockoff (2004) and Rivkin, Hanushek, and Kain (2005) both suggest a one standard deviation increase in teacher quality improves student math scores by about 0.1 standard deviations. Aaronson, Barrow, and Sander (2007) find similar results using high school data. Branch et al (2012) report that a one standard deviation increase in principal leadership (i.e., a principal in the top 16 percent of the quality distribution) leads to 0.05 standard deviation gain in test scores of all students in the school. Chetty (2014b) finds that one standard deviation improvement in teacher value added in a single grade in primary school in NY City raises the

\footnotetext{
${ }^{14}$ Following Morris (1983) and the teacher value added literature (for example, Kane and Staiger 2008) we construct the EB shrinkage factor for superintendent $i$ by the ratio of signal variance to signal variance plus noise variance of superintendent $i$. Similarly to the teacher value added literature, we assume that the measure of superintendent bias includes an error component. Thus, estimating superintendents' effects on students' test scores enables separation of the signal variance (variance of superintendents' effects) and noise variance of superintendent $i$ (variance of the residuals for superintendent $i$ ). The EB estimate for each superintendent is a weighted average of the superintendent estimated effect and the mean of superintendent estimates, where the weight is the EB shrinkage factor. Implementing this methodology, the less reliable estimates of superintendent value added (those with a large variation in estimated residuals) are shrunk towards the mean of superintendent estimates.

15 The bootstrap estimates of the standard errors are constructed as follows. In a first step, a random sample with replacement is drawn from each superintendents' schools. A new measurement of superintendent bias for each superintendent is created, based on the new sample of schools. In a second step, the effect of these new value added measures on student test scores in 5th grade is estimated (based on the preferred specification presented in Table 6) and the coefficients are stored. This process of two-step bootstrap sampling and estimation is repeated 1,000 times. The standard deviations in the sample of 1,000 observations of coefficient estimates from the second step are the bootstrap standard errors of the estimated effects of superintendent value added.
} 
probability of college attendance at age 20 by 0.82 percentage points, relative to a sample mean of $37 \%$. In comparison to other schooling interventions, it would require one additional hour of instruction per week in math, Hebrew and English (a 25 percent increase) in order to achieve the same effect as a one standard deviation increase in superintendent value-added (Lavy 2015).

Since 80 percent of the superintendents in our sample are female, we report in Panel B, third and fourth rows of Table 6 , the estimates from regressions when the sample is restricted to schools with female superintendents. The estimated effect based on the school level means is 0.048 ( $\mathrm{se}=0.022)$ when using the first value added measure and 0.063 ( $\mathrm{se}=0.032$ ) when using the second value added measure, both larger than the full sample estimates but not significantly different from them. The two estimates obtained from the students' sample level regressions are 0.053 and 0.055 .

In Panel $\mathrm{C}$ we present evidence based on sub-samples of students by parental education. Father's or mother's years of schooling are good proxies for student's socio-economic background. Research on the causal impact of school inputs suggest that students from poorer backgrounds benefit more from factors such lower class size, remedial education, higher quality peers and teacher quality. ${ }^{16}$ Our estimates show no such differences with respect to the effect of management quality in public education.

To check for potential non-linearity in the effect of superintendent value added, we report in Table 8 estimates where we divide the distribution to ranges from low to high. First we split the range above and below the median of superintendent's value added. Using value added I, the estimate for the indicator of above median quality is 0.065 ( $\mathrm{se}=0.036$ ) and using value added II yields a marginally higher estimate, 0.082 ( $\mathrm{se}=0.036)$. Secondly, we divide the distribution to quartiles of superintendent's value added. The estimates for three upper quartile value added indicators are increasing monotonically: with value added I the estimates are $0.031,0.055$, and 0.130 . With value added II they are $0.080,0.099$, and 0.135 , suggesting a non-linear effect of superintendent value added with a monotonically increasing effect. The estimated effect of the upper quartile of ability is statistically significantly different from zero for both value added estimates.

Clearly the effect of superintendents' value added is non-linear and it increases sharply with value added. It is natural and interesting to compare this pattern of non-linear effect with that of the effect of teachers' value added but we did not find studies that provide such evidence.

Since the middle school system in Israel (grades 7-9) shares the same model of superintendents as that of primary schools, we replicated the analysis presented above with the data for middle schools. We relied on value added I as the measure of superintendent quality because the sample of schools is much smaller than the primary schools sample: only 15 schools had changed their superintendent from 2002-2003 to 2004-2005 and during the two periods, 13 different superintendents were the CEOs of

\footnotetext{
${ }^{16}$ For example, Angrist and Lavy (1999).
} 
these schools. Using the students' level data, the estimated effect of value added I for middle schools is presented in Table 9. The point estimates are negative in the first three columns but change sign when a school fixed effect is added to the regression as a control. The estimated effect is 0.048 , very close to the respective estimate based on the sample of primary schools $(0.040$, se $=0.016)$ but much less precisely estimated ( $\mathrm{se}=0.055$ ), probably due to the much smaller sample of schools, 15 versus 82 .

\section{Identifying Mechanisms of Effect of Superintendents' Value Added}

The results reported above show that schools exhibit higher achievement when they have a higher value added superintendent. In this section, we explore several potential mechanisms through which superintendents' value added may affect their students' academic achievement. We use a rich set of school practices and outcomes based on responses to questionnaires of primary school principals, teachers and students. ${ }^{17} \mathrm{We}$ focus on items that relate to the classroom and school environment (student questionnaire), on school activities and programs in the area of improving school climate and students' norms and on school resources (principal questionnaire), school procedures and teachers' on and off the job training (teacher questionnaire). To obtain a more general picture of the possible mechanisms and to gain statistical power, we also group outcomes into eight categories. We analyse each category by creating a category-specific average effect. This allows us to control for the potential problem of overrejection of the null hypothesis due to multiple inference. Because different outcomes have different data scales, simply averaging the estimators for the treatment effect is not likely to produce a meaningful statistic. To address this concern, we follow the summary-index approach per Kling et al. (2007). The average effect of multiple outcomes is the average of z-scores of each outcome variable. This summary index is a special case of the z-score and is identical to the mean effect size of treatment if there is no missing value. ${ }^{18}$ In general, the sign of the summary index reveals information on the direction of the

\footnotetext{
${ }^{17}$ See H. Jerome Freiberg (1999) and J. Barry Fraser (1998) for recent reviews of the educational research literature about the validity of students' and teachers' assessments of the classroom environment and their
} associations with students' achievements.

${ }^{18}$ In the regression specification this approach yields standardized estimators as follows: the treatment effects for $K$ outcomes are aggregated and reflected in a single standard normal statistic,

$$
\tau=\frac{1}{K} \sum_{k} \frac{\boldsymbol{\beta}_{1 \mathrm{k}}}{\sigma_{k_{C}}}, \quad k=1, \ldots, K
$$

where $\boldsymbol{\beta}_{1 k}$ indicates the average treatment effect for outcome $k$ and $\sigma_{k_{C}}$ denotes the standard deviation of the $k^{\text {th }}$ control outcome. Having included the covariates, the $K$ average treatment effects $\left(\boldsymbol{\beta}_{\mathbf{1}}\right)$ and sample variances can be easily acquired through a linear regression. By doing so, the above equation can be thought of as a point estimator representing a collection of standardized treatment effects. However, this paper also takes into account the covariance of effects and therefore adapt a seemingly uncorrelated regression (O'Brien 1984, Kling et al. 2007):

$$
\mathbf{Y}=I_{K} \otimes(T \quad X) \beta+v
$$


aggregate impact of a class of outcomes, and the more the summary index deviates from zero, the stronger is the implied aggregate effect.

We are aware, of course, that we are not able to measure all the relevant mechanisms, and we cannot rule out the possibility that other mechanisms are in place, but the analysis presented in this section provides important insights regarding the possible mediating factors that drive the positive effect of the school superintendent on students' achievements. ${ }^{19}$ Our hypothesis is that if the effects of the superintendent value added are partially being driven by a particular mediating factor, observing a significant effect of the superintendent value added on this factor provides some evidence for the validity of this hypothesis. ${ }^{20} \mathrm{We}$ use in this section value added I as our measure of superintendent quality because its estimation is based on sample that is twice as large as the one use to estimate value added II (497 schools versus 226 schools) and it allows for estimating within-school effects.

School Priorities, Working Procedures and Resources: In Table 10 we present evidence about three potential channels for the effect of superintendent value added, priority setting by schools and working procedures, school resources and students' time allocated to homework. Three items in the teacher's questionnaire ("school has clearly defined priorities", "teachers are involved in setting school priorities", and "school has clearly defined working procedures") reflect management practices that can affect the allocation and use of school resources and therefore be conducive or harmful to learning and achievement. Clearly the scope, responsibilities and management directives of superintendent can affect these school factors by the frequent interaction with school principals and teachers. In panel A we present treatment effect estimates for these outcomes, the mean of which are very high, over 5 in a scale of 1-6. The within school estimates show that a higher superintendent value added improves only the first outcome, which reflects student-teacher relationship, but not the others. Panel B of Table 10 provides evidence on the impact of the superintendent's value added on school resources, including outcomes that are less likely to be affected by the superintendent, such as class size and instruction budget per class. These school inputs are determined by national or regional educational authorities and the superintendent should not be able to influence them. Indeed, we find no significant effect on these

where $\boldsymbol{T}$ is the treatment indicator(s), and $\boldsymbol{X}$ consists of controlled regressors as well as a constant term.

${ }^{19}$ A further limitation is that we cannot identify the causal effect of the mechanisms on outcomes because the former are numerous and we have only one potential instrument.

\footnotetext{
${ }^{20}$ Lavy and Schlosser (2011) show in online Appendix Table 5 that all indicators of the quality of the classroom environment, as described by the students, are highly correlated with students' academic performances even after controlling for school fixed effects and students' background characteristics. For example, they report that lower levels of classroom disruption and violence, better inter-student relationships, and a higher quality of interaction between teachers and students are all positively associated with students' test scores. Though they do not provide a causal interpretation to these correlations, their results suggest that students' assessments of their classroom environment have a high informational content and that these mechanisms, as pointed out in the educational literature, might play an important role in student's learning process.
} 
inputs. We also find no significant effects of superintend quality on instruction time on different subjects and on the time students allocate to homework. These results are presented in Panel C.

School climate programs and outcomes: From two items in the school principal questionnaire we define an indicator of whether, in the current year, the school assessed the school climate and norms, and whether it had interventions aiming at improving norms, values, and discipline of students. In panel A of Table 11 we report estimates from regressions when each of these two indicators is the dependent variable. We use three different specifications identical to the three specifications used in Table 6 . Seventy one percent of the schools in the sample had in the current year an assessment of discipline, violence and norms in school and 29 percent of schools had interventions targeted at improving these aspects of the school environment. Superintendents' value added has a positive and statistically significant effect on both of these outcomes. The average effect shows similar positive outcomes.

In panel B of Table 11 we present estimates of the effect of superintendents' value added on classroom and school violence. This analysis is based on the following items from the student's questionnaire: (1) "There are many fights among students in my classroom."; (2) "This year I was involved in many fights" (3) "Sometimes I'm scared to go to school because there are violent students." The estimates reported in panel B columns 2-4 of Table 11 suggest that a higher superintendent value added significantly lowers the level of violence in school. This effect is evident in each of the three items and also in their average effect. For example, the estimate for the effect of superintendent value added on students' reports regarding the level of violence in the classroom is -0.035 ( $\mathrm{se}=0.018$ ). The average effect of these three items is more precise than the estimates for the individual items. The average estimate is -0.033 ( $\mathrm{se}=0.012$ ). Overall, these results suggest that having a higher quality superintendent improves the safety climate in school by lowering the incidence of fights, increasing the safety of students, and lowering their anxiety about attending school.

Three items in the student's questionnaire ("When I have a problem at school there is always someone I can turn to (from the teaching staff)", "I feel well-adjusted socially in my class," and "I am satisfied in school") reflect school environment and climate, in particular the relationships between students and teachers and the quality of inter-student relationships. These factors can be conducive or harmful to learning and achievement. Being well-adjusted and accepted socially among classroom peers may improve a student's self-confidence, self-image, motivation, and other non-cognitive attributes that might be essential for effective learning. ${ }^{21}$ In panel $\mathrm{C}$ we present treatment effect estimates for these outcomes, the means of which are very high, over 5 in a scale of 1-6. The within school estimates show that a higher superintendent value added improves only the first outcome, which reflects student-teacher

\footnotetext{
${ }^{21}$ Table A3 provides further evidence on the relationship between school climate and violence, and students' scores. As the evidence cannot be interpreted as causal, the large and statistical within school conditional correlations with students' scores provide additional support for school climate and violence as a mechanism through which superintendents affect students' outcomes.
} 
relationships, but not the others. The estimates of the social and school satisfaction are positive but they are small and not statistically different from zero, and so is the average effect.

Scholastic Programs and Teachers Training: In Table 12 we present evidence on three additional potential channels for the effect of superintendent's value added: school scholastic programs in Hebrew, math and English, and two forms of teachers' training in each of these three subjects, in service on the job training and external courses. The subject specific programs include additional instructional resources for a given subject or improvements to teaching methods and practices. The effect of superintendent value added is positive and significant in English but not in programs for the other two subjects.

The effect of superintendent quality on teachers' training outside of schools is practically zero, as seen by the estimated effect on external training in each of the three subjects. The estimated effect of on the job training is positive and significant, in math it is positive but not precisely measured, and in English it is negative but not different from zero. The average effect is positive but imprecise, suggesting that the overall effect is negligible but the effect on the composition of the in school training is meaningful. Angrist and Lavy (2001) estimated a large effect of such in school training on students' test scores.

Changing School's Principal: In Table 13 we present evidence on another important channel for the effect of superintendent value added, changing the school principal. About 15 percent of the schools change their principal every year, implying that the mean duration of a school principal is 6-7 years. In columns 1-3 we present estimates of the effect of an indicator of change in the school superintendent on the probability of a school changing its principal. This likelihood is lower by about 6 percent in the year a new superintendent steps in, and it is 9 percent higher the following year. When both the contemporaneous and one year lagged effect are included jointly the estimates change marginally, though the pattern is the same. In columns 4-9 we present the estimates for each year separately. Most interesting are the results for the academic year 2004-2005, because we can estimate the contemporaneous effect and the one and two year lag effects. The pattern that emerges is striking: the likelihood of a change in school principal in a new superintendent's first year is lower by 7.6 percent; higher by 14 percent in the second year, and zero in the third year. These estimates clearly suggest that a change in school management is associated with the engagement of a new superintendent.

\section{Concluding Remarks}

This is the first paper that measures the causal effect of the quality of management-supervision in public education. The structure of the education system in Israel, as in many other countries, includes a superintendent who is the CEO of a group of about 15 schools over which she/he has extensive responsibility and authority. We exploit quasi-random turnover of superintendents over time to measure their value added in terms of test score gains in English, Hebrew and math in primary schools in Israel. This turnover is largely dictated by a routine in the system to rotate superintendents across schools every 
3-5 years, and by other naturally occurring events such as retirement of superintendents. We show that geographical considerations largely determine which schools are included in a superintendent's cluster of schools. We further demonstrate that the turnover of superintendents is unrelated to schools or students' potential outcomes. We measure superintendents' value added similarly to recent measures of teachers' value added, including controls for school level lagged outcomes. We construct two alternative value added measures: the first based on the common academic achievement level of all schools that share the same superintendent, the second based on the common growth in academic achievement shared by all schools that were assigned to the same new superintendent. We then show that both measures of superintendents' value added are uncorrelated with the probability that superintendents experience turnover of schools.

We estimate that superintendent value added has positive and significant effects on primary students' test scores in math, Hebrew, and English. Based on the first value added measure, one standard deviation improvement in superintendent value added increases test scores by about 0.04 standard deviations in the test score distribution. The effect is similar for students from lower and higher socioeconomic backgrounds, it is highly non-linear, increasing sharply for superintendents in the highest quartile of the value added distribution, and larger but not statistically significantly so for female superintendents. We obtain similar results when using the second measure of value added. We explore several mechanisms for these effects and find that superintendents with higher value added are associated with more focused school priorities and more clearly defined working procedures, but no effect on school resources - as funding is determined centrally at the Ministry of Education, and no effect on teachers' on the job and external training. Schools with higher quality superintendents are more likely to address school climate, violence and bullying, and implement interventions that lead to lower violence in school and higher social school satisfaction among students. It is interesting to note that this channel of effect of reducing violence and bullying in school is consistent with the strong discipline 'no excuse' philosophy of charter schools (Dobbie and Fryer 2013, Angrist, Pathak and Walters 2013) which also was effective in improving school outcomes when implemented in noncharter public schools (Fryer 2014).

Two additional remarks point to the relevance of our findings for public policy. First we note that the effect size of superintendent's value added is particularly cost effective, because an increase in the quality of one manager can improve the outcomes of thousands of students. Therefore, investing in the quality of these 'CEOs' of schools is very compelling resource wise, relative to investment in other school inputs, for example teacher quality. Secondly, about 70 percent of all superintendents are women, very different to the relative scarcity of women in leadership roles in other public sector management roles, and in the private sector. Our findings suggest that the quality of women as superintendents does not fall short of that of men in the same position, raising the policy concern of 
why there are so few women in leadership roles even in the public sector, and how allocative efficiency can be improved in this regard in the labor market.

\section{References}

Angrist JD, Pathak PA, Walters CR. Explaining Charter School Effectiveness. American Economic Journal: Applied Economics. 2013; 5(4):1-27.

Angrist, Joshua D., and Victor Lavy. 1999. "Using Maimonides Rule to Estimate the Effect of Class Size on Scholastic Achievement." Quarterly Journal of Economics 114(2):533-75.

Angrist, Joshua D., and Victor Lavy. 2001. "The Effect of Teachers' Training on Student Achievements." Journal of Labor Economics, volume 19, no. 2, pp. 343-369.

Aaronson, Daniel, Lisa Barrow, and William Sander. 2007. "Teachers and Student Achievement in the Chicago Public High Schools." Journal of Labor Economics 25(1):95-135.

Bacher-Hicks, A., T. J. Kane, and D. O. Staiger (2014): "Validating Teacher Effect Estimates Using Changes in Teacher Assignments in Los Angeles," Working paper 20657, National Bureau of Economic Research.

Banerjee. A., R. Chattopadhyay, E. Duflo, D. Keniston and N. Singh (2014) "Improving Police Performance in Rajasthan, India: Experimental Evidence on Incentives, Managerial Autonomy and Training", mimeo, MIT.

Benabou. R, and J. Tirole (2006) "Intrinsic and Extrinsic Motivation," Review of Economic Studies 70: 489-520.

Bertrand Marianne and Antoinette Schoar, "Managing with Style: The Effect of Managers on Firm Policies" , The Quarterly Journal of Economics, November 2003, 118(4), pp. 1169-1208.

Besley. T and M. Ghatak (2005) "Competition and Incentives with Motivated Agents," American Economic Review 95: 616-36.

Bloom. N and J. Van Reenen (2007) "Measuring and Explaining Management Practices Across Firms and Countries," Quarterly Journal of Economics 122: 1351-1408.

Bloom. N and J. Van Reenen (2010) "New Approaches to Surveying Organizations," American Economic Review 100: 105-9.

Bloom. N, Renata Lemos, Raffaella Sadun and J. Van Reenen (2015) "Does Management Matter in Schools?" Economic Journal Vol. 125, No. 584: 647-674.

Branch, Gregory F., Eric A. Hanushek, and Steven G. Rivkin. 2012. 'Estimating the Effect of Leaders on Public Sector Productivity: The Case of School Principals'. Working Paper 17803. National Bureau of Economic Research.

Bryson, Alex, Lucy Stokes and David Wilkinson (2017) “Can HRM Improve Schools' Performance?” Manuscript, October. 
Chetty, R., J. N. Friedman, and J. E. Rockoff, (2014a): "Measuring the Impacts of Teachers I: Evaluating Bias in Teacher Value-Added Estimates," American Economic Review, 104, $2593-$ 2632.

Chetty, R., J. N. Friedman, and J. E. Rockoff, (2014b): "Measuring the Impacts of Teachers II: Teacher Value-Added and Student Outcomes in Adulthood," American Economic Review, 104, 26332679.

Clark, Damon, Paco Martorell, and Jonah E. Rockoff. 2009. 'School Principals and School Performance'. 38. CALDER Working Papers. Center for Analysis of Longitudinal Data in Education Research.

Dal Bo. E, F. Finan and M. Rossi (2013) "Strengthening State Capabilities: The Role of Financial Incentives in the Call to Public Service," Quarterly Journal of Economics 128: 1169-218.

Di Liberto. A, F. Schivardi and G. Sulis (2013) "Managerial Practices and Students' Performance," mimeo, LUISS.

Dobbie W, Fryer Jr. RG. Getting beneath the veil of effective schools: Evidence from New York City. American Economic Journal: Applied Economics. 2013; 5(4):28-60.

Fehr. E, H. Herz and T. Wilkening (2013) "The Lure of Authority: Motivation and Incentive Effects of Power," American Economic Review 103: 1325-59.

Fryer RG. Injecting charter schools best practices into traditional public schools: Evidence from field experiments. The Quarterly Journal of Economics. 2014;129(3):1355-1407.

Grissom, Jason A., and Susanna Loeb. 2011. 'Triangulating Principal Effectiveness How Perspectives of Parents, Teachers, and Assistant Principals Identify the Central Importance of Managerial Skills'. American Educational Research Journal 48(5):1091-1123.

Hanushek, Eric A., Susanne Link, and Ludger Woessmann. 2013. 'Does School Autonomy Make Sense Everywhere? Panel Estimates from PISA'. Journal of Development Economics 104 (September): $212-32$.

Horng, Eileen Lai, Daniel Klasik, and Susanna Loeb. 2010. 'Principal's Time Use and School Effectiveness'. American Journal of Education 116 (4): 491-523.

Imran Rasul, and Daniel Roggery, "Management of Bureaucrats and Public Service Delivery: Evidence from the Nigerian Civil Service," June 2015.

Jacob, Brian A., and Lars Lefgren and David P. Sims, 2010. "The Persistence of Teachers-Induced Learning”, Journal of Human Resources 45(4):915-943.

Kane, T. J., D. F. McCaffrey, T. Miller, and D. O. Staiger (2013), "Have We Identified Effective Teachers? Validating Measures of Effective Teaching Using Random Assignment," Research paper, Bill \& Melinda Gates Foundation, Seattle, Washington.

Kane, T. J., and Staiger, D. O., 2008. Estimating Teacher Impacts on Student Achievement: An Experimental Evaluation, NBER Working Paper No. 14607. 
Kling, Jeffrey R., Jeffrey B. Liebman, and Lawrence F. Katz. "Experimental analysis of neighborhood effects." Econometrica 75.1, 2007, 83-119.

Lavy Victor and Analia Schlosser (2011) "Mechanisms and Impacts of Gender Peer Effects at School" American Economic Journal: Applied Economics 3 (April): 1-33.

Lavy Victor "Expanding School Resources and Increasing Time on Task: Effects of a Policy Experiment in Israel on Student Academic Achievement and Behavior”, Draft 2017.

McCormack, John, Carol Propper, and Sarah Smith. 2014. 'Herding Cats? Management and University Performance'. The Economic Journal 124 (578): 534-564.

Morris, C. 1983. "Parametric Empirical Bayes Inference: Theory and Applications". Journal of the American Statistical Association 78, 47-55.Murnane, R.J., J.B. Willett and F. Levy, 1995. "The Growing Importance of Cognitive Skills in Wage Determination”, Review of Economics and Statistics 77, 251-266.

Rivkin, Steven G., Eric A. Hanushek, and John F. Kain. 2005. "Teachers, Schools, and Academic Achievement." Econometrica 73(2):417-58.

Rockoff, Jonah E. 2004. “The Impact of Individual Teachers on Student Achievement: Evidence from Panel Data," American Economic Review 94(2):247-52.

Rothstein, J. (2009), "Student Sorting And Bias In Value-Added Estimation: Selection On Observables And Unobservables," Education Finance and Policy, 4, 537-571.

Rothstein, J. (2010), “Teacher Quality in Educational Production: Tracking, Decay, and Student Achievement," Quarterly Journal of Economics, 125, 175-214.

(2015): “Teacher Quality Policy When Supply Matters," American Economic Review, 105, $100-130$.

- (2016): "Revisiting the Impacts of Teachers," Manuscript, March.

Woessmann, Ludger, Elke Lüdemann, Gabriela Schütz, and Martin R. West. 2007. 'School Accountability, Autonomy, Choice, and the Level of Student Achievement'. OECD Education Working Papers 13. Paris: OECD Publishing. 


\begin{tabular}{|c|c|c|c|c|}
\hline & \multicolumn{4}{|c|}{ Year } \\
\hline & 2002 & 2003 & 2004 & 2005 \\
\hline \multicolumn{5}{|l|}{ A. All Superintendents } \\
\hline Number of Superintendents & 54 & 56 & 57 & 54 \\
\hline Number of Schools & 810 & 807 & 803 & 797 \\
\hline Number of Schools per Superintendent & $\begin{array}{c}16.1 \\
(4.92)\end{array}$ & $\begin{array}{c}15.5 \\
(5.67)\end{array}$ & $\begin{array}{c}15.1 \\
(5.52)\end{array}$ & $\begin{array}{c}15.9 \\
(6.10)\end{array}$ \\
\hline \multicolumn{5}{|l|}{ Male Sample } \\
\hline Number of Superintendents & 14 & 15 & 13 & 10 \\
\hline Number of Schools & 163 & 163 & 150 & 108 \\
\hline Number of Schools per Superintendent & $\begin{array}{c}13.9 \\
(4.43)\end{array}$ & $\begin{array}{c}12.9 \\
(5.11)\end{array}$ & $\begin{array}{c}13.6 \\
(4.72)\end{array}$ & $\begin{array}{c}13.5 \\
(4.20)\end{array}$ \\
\hline \multicolumn{5}{|l|}{ Female Sample } \\
\hline Number of Superintendents & 40 & 41 & 44 & 44 \\
\hline Number of Schools & 647 & 644 & 653 & 689 \\
\hline Number of Schools per Superintendent & $\begin{array}{c}16.9 \\
(4.90)\end{array}$ & $\begin{array}{c}16.4 \\
(5.64)\end{array}$ & $\begin{array}{c}15.5 \\
(5.71)\end{array}$ & $\begin{array}{c}16.4 \\
(6.38)\end{array}$ \\
\hline \multicolumn{5}{|l|}{ B. Superintendents with Turnover of Schools } \\
\hline Number of Superintendents & - & 35 & 21 & 26 \\
\hline Number of Schools & - & 563 & 309 & 448 \\
\hline Number of Schools per Superintendent & $\cdot$ & $\begin{array}{c}16.7 \\
(5.24)\end{array}$ & $\begin{array}{c}15.8 \\
(3.95)\end{array}$ & $\begin{array}{c}18.4 \\
(5.35)\end{array}$ \\
\hline \multicolumn{5}{|l|}{ C. Superintendents with Net Turnover of Schools $>0$} \\
\hline Number of Superintendents & - & 15 & 9 & 11 \\
\hline Number of Schools & - & 277 & 135 & 234 \\
\hline \multirow[t]{2}{*}{ Number of Schools per Superintendent } & $\cdot$ & 18.9 & 16.0 & 22.1 \\
\hline & & $(4.03)$ & $(3.64)$ & $(4.48)$ \\
\hline \multicolumn{5}{|l|}{ D. Superintendents with Net Turnover of Schools $<0$} \\
\hline Number of Superintendents & - & 18 & 10 & 11 \\
\hline Number of Schools & - & 238 & 142 & 135 \\
\hline Number of Schools per Superintendent & $\cdot$ & $\begin{array}{c}14.1 \\
(4.76)\end{array}$ & $\begin{array}{c}15.0 \\
(4.22)\end{array}$ & $\begin{array}{c}14.3 \\
(3.69)\end{array}$ \\
\hline \multicolumn{5}{|l|}{ E. Final Analysis Sample of Superintendents } \\
\hline Number of Superintendents & 27 & 29 & 29 & 26 \\
\hline Number of Schools & 428 & 461 & 461 & 445 \\
\hline Number of Schools per Superintendent & $\begin{array}{c}16.7 \\
(5.40)\end{array}$ & $\begin{array}{c}16.6 \\
(5.24)\end{array}$ & $\begin{array}{c}16.7 \\
(4.75)\end{array}$ & $\begin{array}{c}18.0 \\
(5.72)\end{array}$ \\
\hline \multicolumn{5}{|c|}{ F. Retirement of Veteran Superintendents and Introduction of New Superintendents } \\
\hline Number of New Superintendents & 8 & 6 & 5 & 4 \\
\hline Number of Schools per New Superintendent & $\begin{array}{c}13.1 \\
(6.53)\end{array}$ & $\begin{array}{c}12.5 \\
(6.72)\end{array}$ & $\begin{array}{c}11.5 \\
(6.94)\end{array}$ & $\begin{array}{c}13.9 \\
(7.36)\end{array}$ \\
\hline Number of Retiring Superintendents (at year's end) & 4 & 4 & 7 & $\cdot$ \\
\hline Number of Schools per Retiring Superintendent & $\begin{array}{c}13.6 \\
(3.69)\end{array}$ & $\begin{array}{c}12.3 \\
(6.00)\end{array}$ & $\begin{array}{c}13.7 \\
(5.91)\end{array}$ & $\cdot$ \\
\hline Average number of New SIs' Schools from Retired SIs & $\cdot$ & 2.5 & 5.6 & 12.0 \\
\hline & $\cdot$ & $(3.02)$ & $(4.83)$ & $(7.57)$ \\
\hline
\end{tabular}

Notes: Standard deviations are presented in parenthesis. The sample includes all schools in the jewish non-religious primary school system. 


\begin{tabular}{|c|c|c|c|c|}
\hline & \multicolumn{2}{|c|}{ Period 0: 2002-2003 } & \multicolumn{2}{|c|}{ Period 1: 2004-2005 } \\
\hline & $\begin{array}{c}\text { Mean (SD) } \\
(1) \\
\end{array}$ & $\begin{array}{c}\text { Regression } \\
\text { Coefficient } \\
\text { (2) } \\
\end{array}$ & $\begin{array}{c}\text { Mean (SD) } \\
\text { (3) } \\
\end{array}$ & $\begin{array}{c}\text { Regression } \\
\text { Coefficient } \\
\text { (4) } \\
\end{array}$ \\
\hline \multicolumn{5}{|l|}{ School Average Characteristics } \\
\hline Male & $\begin{array}{c}0.508 \\
(0.500)\end{array}$ & $\begin{array}{l}-0.130 \\
(0.013)\end{array}$ & $\begin{array}{c}0.504 \\
(0.500)\end{array}$ & $\begin{array}{l}-0.106 \\
(0.012)\end{array}$ \\
\hline Number of Siblings & $\begin{array}{l}2.115 \\
(1.194)\end{array}$ & $\begin{array}{l}-0.050 \\
(0.004)\end{array}$ & $\begin{array}{c}2.114 \\
(1.204)\end{array}$ & $\begin{array}{l}-0.049 \\
(0.006)\end{array}$ \\
\hline Immigrant & $\begin{array}{c}0.147 \\
(0.354)\end{array}$ & $\begin{array}{c}-0.093 \\
(0.083)\end{array}$ & $\begin{array}{c}0.118 \\
(0.322)\end{array}$ & $\begin{array}{l}-0.219 \\
(0.120)\end{array}$ \\
\hline Father's Education & $\begin{array}{l}12.625 \\
(3.542)\end{array}$ & $\begin{array}{c}0.033 \\
(0.002)\end{array}$ & $\begin{array}{l}12.613 \\
(3.641)\end{array}$ & $\begin{array}{c}0.026 \\
(0.003)\end{array}$ \\
\hline Mother's Education & $\begin{array}{l}12.968 \\
(3.067)\end{array}$ & $\begin{array}{c}0.048 \\
(0.003)\end{array}$ & $\begin{array}{l}12.965 \\
(3.271)\end{array}$ & $\begin{array}{c}0.035 \\
(0.003)\end{array}$ \\
\hline Ethnicity - Asia Africa & $\begin{array}{c}0.146 \\
(0.353)\end{array}$ & $\begin{array}{l}-0.031 \\
(0.013)\end{array}$ & $\begin{array}{c}0.096 \\
(0.295)\end{array}$ & $\begin{array}{l}-0.045 \\
(0.019)\end{array}$ \\
\hline Ethnicity - Europe America & $\begin{array}{c}0.159 \\
(0.365)\end{array}$ & $\begin{array}{c}0.063 \\
(0.016)\end{array}$ & $\begin{array}{c}0.154 \\
(0.361)\end{array}$ & $\begin{array}{c}0.082 \\
(0.014)\end{array}$ \\
\hline Ethnicity - Ethiopia & $\begin{array}{c}0.019 \\
(0.137)\end{array}$ & $\begin{array}{l}-0.223 \\
(0.074)\end{array}$ & $\begin{array}{c}0.017 \\
(0.130)\end{array}$ & $\begin{array}{l}-0.130 \\
(0.045)\end{array}$ \\
\hline Ethnicity - Former USSR & $\begin{array}{c}0.109 \\
(0.312)\end{array}$ & $\begin{array}{c}0.011 \\
(0.099)\end{array}$ & $\begin{array}{c}0.086 \\
(0.281)\end{array}$ & $\begin{array}{c}0.252 \\
(0.125)\end{array}$ \\
\hline Ethnicity - Other & $\begin{array}{c}0.032 \\
(0.176)\end{array}$ & $\begin{array}{c}0.101 \\
(0.088)\end{array}$ & $\begin{array}{c}0.027 \\
(0.163)\end{array}$ & $\begin{array}{c}0.239 \\
(0.126)\end{array}$ \\
\hline Number of classes in the school & $\begin{array}{l}15.757 \\
(3.837)\end{array}$ & $\begin{array}{c}0.001 \\
(0.009)\end{array}$ & $\begin{array}{l}15.846 \\
(3.983)\end{array}$ & $\begin{array}{c}0.001 \\
(0.009)\end{array}$ \\
\hline Number of students in the school & $\begin{array}{c}461.931 \\
(144.421)\end{array}$ & $\begin{array}{c}0.000 \\
(0.000)\end{array}$ & $\begin{array}{c}458.217 \\
(147.471)\end{array}$ & $\begin{array}{c}0.000 \\
(0.000)\end{array}$ \\
\hline \multicolumn{5}{|l|}{ School Average Lagged Z-Score } \\
\hline 1991 4th Grade Math & $\begin{array}{c}0.017 \\
(0.876)\end{array}$ & $\begin{array}{c}0.013 \\
(0.031)\end{array}$ & $\begin{array}{c}0.018 \\
(0.863)\end{array}$ & $\begin{array}{l}-0.008 \\
(0.031)\end{array}$ \\
\hline 1991 4th Grade Verbal & $\begin{array}{c}0.002 \\
(0.864)\end{array}$ & $\begin{array}{c}0.018 \\
(0.030)\end{array}$ & $\begin{array}{c}0.009 \\
(0.852)\end{array}$ & $\begin{array}{c}0.048 \\
(0.034)\end{array}$ \\
\hline 1991 5th Grade Math & $\begin{array}{c}0.028 \\
(0.882)\end{array}$ & $\begin{array}{l}-0.044 \\
(0.023)\end{array}$ & $\begin{array}{c}0.029 \\
(0.876)\end{array}$ & $\begin{array}{c}0.003 \\
(0.023)\end{array}$ \\
\hline 1991 5th Grade Verbal & $\begin{array}{c}0.005 \\
(0.869)\end{array}$ & $\begin{array}{c}0.041 \\
(0.027)\end{array}$ & $\begin{array}{c}0.009 \\
(0.860)\end{array}$ & $\begin{array}{c}0.013 \\
(0.029)\end{array}$ \\
\hline Year FE & - & Yes & $\cdot$ & Yes \\
\hline Subject FE & - & Yes & $\cdot$ & Yes \\
\hline District FE & - & Yes & - & Yes \\
\hline Superintendent FE & $\cdot$ & Yes & $\cdot$ & Yes \\
\hline Number of Students & 32,805 & 32,805 & 31,174 & 31,174 \\
\hline Number of Schools & 497 & 497 & 497 & 497 \\
\hline Number of Superintendents & 47 & 47 & 47 & 47 \\
\hline $\begin{array}{l}\text { Notes : In columns (1) and (3) standard d } \\
\text { superintendent level. Schools characteri } \\
\text { Students' characteristics include gender } \\
\text { religious primary school system. Samp }\end{array}$ & $\begin{array}{l}\text { columns (2) a } \\
\text { of students and } \\
\text { oer of siblings } \\
\text { nglish tests sco }\end{array}$ & $\begin{array}{l}\text { standard erro } \\
\text { umber of schoc } \\
\text { mmigrant statu } \\
\text { Test scores are }\end{array}$ & $\begin{array}{l}\text { arenthesis ar } \\
\text { der the schoo. } \\
\text { schools are i }\end{array}$ & $\begin{array}{l}\text { ered at the } \\
\text { rrintendent. } \\
\text { ewish non- } \\
\text { an and unit sd. }\end{array}$ \\
\hline
\end{tabular}




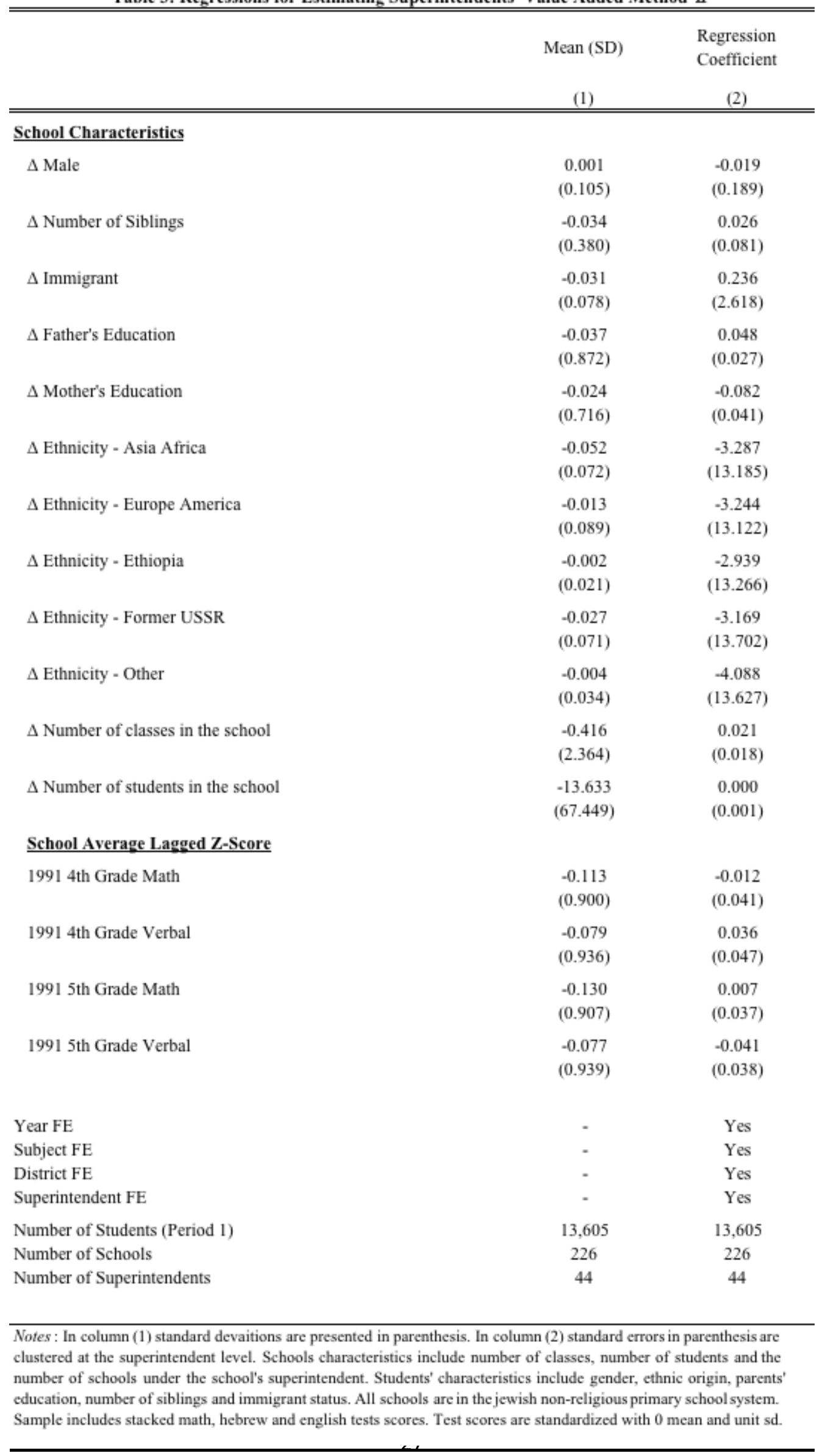


Table 4: Balancing Tests on Probability of Schools Changing Superintendent and on Superintendents' Value Added

\begin{tabular}{|c|c|c|c|c|c|}
\hline & \multicolumn{3}{|c|}{ Changing Superintndent } & \multicolumn{2}{|c|}{ Superintndent Value Added } \\
\hline & $\begin{array}{l}\text { Mean of Schools } \\
\text { that did not } \\
\text { change } \\
\text { Superintendent } \\
\text { (1) } \\
\end{array}$ & $\begin{array}{l}\text { Mean of Schools } \\
\text { that did change } \\
\text { Superintendent } \\
\text { (2) } \\
\end{array}$ & $\begin{array}{l}\text { Probability of } \\
\text { Changing } \\
\text { Superintendent } \\
\text { (3) } \\
\end{array}$ & $\begin{array}{c}\text { Method I } \\
\text { (4) } \\
\end{array}$ & $\begin{array}{c}\text { Method II } \\
\text { (5) } \\
\end{array}$ \\
\hline \multicolumn{6}{|c|}{ A. Student and School Characteristics } \\
\hline Male & $\begin{array}{c}0.506 \\
(0.500)\end{array}$ & $\begin{array}{c}0.502 \\
(0.500)\end{array}$ & $\begin{array}{l}-0.004 \\
(0.004)\end{array}$ & $\begin{array}{l}0.009^{\circ} \\
(0.005)\end{array}$ & $\begin{array}{c}0.009 \\
(0.006)\end{array}$ \\
\hline Number of siblings & $\begin{array}{l}2.115 \\
(1.199)\end{array}$ & $\begin{array}{l}2.127 \\
(1.164)\end{array}$ & $\begin{array}{l}0.013 \\
(0.035)\end{array}$ & $\begin{array}{l}0.008 \\
(0.031)\end{array}$ & $\begin{array}{c}0.032 \\
(0.092)\end{array}$ \\
\hline Immigrant & $\begin{array}{c}0.133 \\
(0.339)\end{array}$ & $\begin{array}{c}0.139 \\
(0.346)\end{array}$ & $\begin{array}{l}0.006 \\
(0.010)\end{array}$ & $\begin{array}{l}-0.007 \\
(0.017)\end{array}$ & $\begin{array}{c}0.004 \\
(0.012)\end{array}$ \\
\hline Mother's years of education & $\begin{array}{l}12.966 \\
(3.168)\end{array}$ & $\begin{array}{l}13.033 \\
(3.184)\end{array}$ & $\begin{array}{c}0.067 \\
(0.114)\end{array}$ & $\begin{array}{c}0.153 \\
(0.179)\end{array}$ & $\begin{array}{l}-0.262 \\
(0.224)\end{array}$ \\
\hline Father's years of education & $\begin{array}{l}12.619 \\
(3.591)\end{array}$ & $\begin{array}{l}12.680 \\
(3.654)\end{array}$ & $\begin{array}{c}0.061 \\
(0.129)\end{array}$ & $\begin{array}{c}0.202 \\
(0.223)\end{array}$ & $\begin{array}{l}-0.301 \\
(0.233)\end{array}$ \\
\hline Ethnicity - Israel & $\begin{array}{c}0.576 \\
(0.494)\end{array}$ & $\begin{array}{c}0.587 \\
(0.492)\end{array}$ & $\begin{array}{c}0.011 \\
(0.013)\end{array}$ & $\begin{array}{l}0.036^{\circ} \\
(0.020)\end{array}$ & $\begin{array}{c}-0.027 \\
(0.022)\end{array}$ \\
\hline Ethnicity - Asia Africa & $\begin{array}{l}0.122 \\
(0.327)\end{array}$ & $\begin{array}{c}0.114 \\
(0.318)\end{array}$ & $\begin{array}{l}-0.007 \\
(0.005)\end{array}$ & $\begin{array}{l}-0.006 \\
(0.009)\end{array}$ & $\begin{array}{c}0.006 \\
(0.007)\end{array}$ \\
\hline Ethnicity - Europe America & $\begin{array}{c}0.157 \\
(0.363)\end{array}$ & $\begin{array}{c}0.154 \\
(0.361)\end{array}$ & $\begin{array}{c}-0.003 \\
(0.006)\end{array}$ & $\begin{array}{l}-0.020^{*} \\
(0.006)\end{array}$ & $\begin{array}{c}0.000 \\
(0.014)\end{array}$ \\
\hline Ethnicity - Ethiopia & $\begin{array}{c}0.018 \\
(0.134)\end{array}$ & $\begin{array}{c}0.010 \\
(0.097)\end{array}$ & $\begin{array}{l}-0.009^{*} \\
(0.003)\end{array}$ & $\begin{array}{l}-0.002 \\
(0.003)\end{array}$ & $\begin{array}{l}0.018^{\circ} \\
(0.006)\end{array}$ \\
\hline Ethnicity - Former USSR & $\begin{array}{c}0.098 \\
(0.297)\end{array}$ & $\begin{array}{c}0.099 \\
(0.299)\end{array}$ & $\begin{array}{c}0.001 \\
(0.010)\end{array}$ & $\begin{array}{c}0.000 \\
(0.014)\end{array}$ & $\begin{array}{c}0.007 \\
(0.015)\end{array}$ \\
\hline Ethnicity - Other & $\begin{array}{l}0.030 \\
(0.170)\end{array}$ & $\begin{array}{c}0.036 \\
(0.187)\end{array}$ & $\begin{array}{c}0.007 \\
(0.003)\end{array}$ & $\begin{array}{l}-0.008 \\
(0.008)\end{array}$ & $\begin{array}{l}-0.004 \\
(0.004)\end{array}$ \\
\hline School's Number of Students & $\begin{array}{c}460.121 \\
(145.927)\end{array}$ & $\begin{array}{c}451.097 \\
(152.871)\end{array}$ & $\begin{array}{c}-9.022 \\
(13.432)\end{array}$ & $\begin{array}{l}-24.821^{*} \\
(14.677)\end{array}$ & $\begin{array}{c}29.176 \\
(19.242)\end{array}$ \\
\hline School's Number of Classes & $\begin{array}{l}15.800 \\
(3.909)\end{array}$ & $\begin{array}{l}15.668 \\
(4.185)\end{array}$ & $\begin{array}{l}-0.132 \\
(0.357)\end{array}$ & $\begin{array}{l}-0.638 \\
(0.423)\end{array}$ & $\begin{array}{c}0.714 \\
(0.537)\end{array}$ \\
\hline \multicolumn{6}{|l|}{ B. Tests' Z-scores 2002-2005 } \\
\hline Math & $\begin{array}{l}-0.001 \\
(1.004)\end{array}$ & $\begin{array}{c}0.010 \\
(0.986)\end{array}$ & $\begin{array}{c}0.011 \\
(0.025)\end{array}$ & $\begin{array}{c}0.002 \\
(0.017)\end{array}$ & $\begin{array}{c}0.052 \\
(0.077)\end{array}$ \\
\hline Hebrew & $\begin{array}{c}0.006 \\
(0.998)\end{array}$ & $\begin{array}{l}-0.005 \\
(0.998)\end{array}$ & $\begin{array}{l}-0.011 \\
(0.026)\end{array}$ & $\begin{array}{l}-0.035 \\
(0.041)\end{array}$ & $\begin{array}{l}-0.009 \\
(0.053)\end{array}$ \\
\hline English & $\begin{array}{l}-0.002 \\
(0.999)\end{array}$ & $\begin{array}{c}0.011 \\
(1.005)\end{array}$ & $\begin{array}{c}0.013 \\
(0.034)\end{array}$ & $\begin{array}{l}-0.028 \\
(0.074)\end{array}$ & $\begin{array}{c}0.000 \\
(0.089)\end{array}$ \\
\hline \multicolumn{6}{|c|}{$\begin{array}{l}\text { C. Correlation Between Previous and Current School's } \\
\text { Superintendent Value Added Based on Method I }\end{array}$} \\
\hline \multicolumn{6}{|c|}{$\begin{aligned} S I(V A)_{t+1}=- & -0.153+0.0916 * S I(V A)_{t} \\
& (0.197)(0.222)\end{aligned}$} \\
\hline Number of Schools & 497 & 222 & 719 & 301 & 82 \\
\hline Number of Superintendents & 47 & 55 & 67 & 30 & 29 \\
\hline
\end{tabular}


Table 5: Distribution of the Change of Superintendent Value Added Within Schools, Method I

\begin{tabular}{|c|c|c|c|c|c|c|}
\hline & $\begin{array}{c}\text { Mean } \\
\text { Change } \\
\text { (1) } \\
\end{array}$ & $\begin{array}{l}\mathrm{SD} \\
(2) \\
\end{array}$ & $\begin{array}{l}\text { Min } \\
\text { (4) } \\
\end{array}$ & $\begin{array}{c}\text { Median } \\
\text { (5) } \\
\end{array}$ & $\begin{array}{l}\text { Max } \\
(6) \\
\end{array}$ & $\begin{array}{c}\text { Schools } \\
\text { (7) } \\
\end{array}$ \\
\hline Full Sample & $\begin{array}{c}0.091 \\
(0.154)\end{array}$ & 1.341 & -3.467 & 0.228 & 2.213 & 82 \\
\hline Female Superintendents Subsample & $\begin{array}{c}0.383 \\
(0.177)\end{array}$ & 1.342 & -3.467 & 0.572 & 2.213 & 64 \\
\hline
\end{tabular}

Notes : Robust standard errors are presented in parenthesis. All schools are in the jewish non-religious primary school system. The sample includes stacked math, hebrew and english tests scores. Superintendents value added is standardized with 0 mean and unit sd. 
Table 6: The Effect of Superintendent Value Added on Tests Z-Scores

\begin{tabular}{|c|c|c|c|c|c|c|c|}
\hline & \multicolumn{4}{|c|}{ Value Added Method I } & \multicolumn{3}{|c|}{ Value Added Method II } \\
\hline & (1) & $(2)$ & (3) & (4) & $(5)$ & (6) & (7) \\
\hline \multicolumn{8}{|l|}{ A. Full Sample } \\
\hline Schools' Sample Regressions & $\begin{array}{c}-0.002 \\
(0.026)\end{array}$ & $\begin{array}{c}-0.002 \\
(0.026)\end{array}$ & $\begin{array}{c}-0.010 \\
(0.017)\end{array}$ & $\begin{array}{c}0.038 \\
(0.019)\end{array}$ & $\begin{array}{c}0.037 \\
(0.041)\end{array}$ & $\begin{array}{c}0.037 \\
(0.041)\end{array}$ & $\begin{array}{c}0.058 \\
(0.030)\end{array}$ \\
\hline Students' Sample Regressions & $\begin{array}{c}0.003 \\
(0.025)\end{array}$ & $\begin{array}{c}0.003 \\
(0.025)\end{array}$ & $\begin{array}{c}-0.013 \\
(0.018)\end{array}$ & $\begin{array}{c}0.040 \\
(0.016)\end{array}$ & $\begin{array}{c}0.035 \\
(0.041)\end{array}$ & $\begin{array}{c}0.035 \\
(0.041)\end{array}$ & $\begin{array}{c}0.051 \\
(0.032)\end{array}$ \\
\hline \multicolumn{8}{|l|}{ B. Female Superintendents Sample } \\
\hline Schools' Sample Regressions & $\begin{array}{c}0.010 \\
(0.029)\end{array}$ & $\begin{array}{c}0.010 \\
(0.029)\end{array}$ & $\begin{array}{c}-0.007 \\
(0.020)\end{array}$ & $\begin{array}{c}0.048 \\
(0.022)\end{array}$ & $\begin{array}{c}0.035 \\
(0.043)\end{array}$ & $\begin{array}{c}0.035 \\
(0.043)\end{array}$ & $\begin{array}{c}0.061 \\
(0.032)\end{array}$ \\
\hline Students' Sample Regressions & $\begin{array}{c}0.019 \\
(0.028)\end{array}$ & $\begin{array}{c}0.019 \\
(0.028)\end{array}$ & $\begin{array}{c}-0.007 \\
(0.019)\end{array}$ & $\begin{array}{c}0.053 \\
(0.011)\end{array}$ & $\begin{array}{c}0.034 \\
(0.043)\end{array}$ & $\begin{array}{c}0.034 \\
(0.043)\end{array}$ & $\begin{array}{c}0.053 \\
(0.034)\end{array}$ \\
\hline \multicolumn{8}{|c|}{ C. Full Sample - By Parental Education (Student Level) } \\
\hline Below Median Father's Years of Schooling & $\begin{array}{c}-0.016 \\
(0.024)\end{array}$ & $\begin{array}{l}-0.016 \\
(0.024)\end{array}$ & $\begin{array}{c}-0.023 \\
(0.029)\end{array}$ & $\begin{array}{c}0.047 \\
(0.027)\end{array}$ & $\begin{array}{c}0.046 \\
(0.042)\end{array}$ & $\begin{array}{c}0.046 \\
(0.042)\end{array}$ & $\begin{array}{c}0.050 \\
(0.036)\end{array}$ \\
\hline Above Median Father's Years of Schooling & $\begin{array}{c}0.010 \\
(0.023)\end{array}$ & $\begin{array}{c}0.010 \\
(0.023)\end{array}$ & $\begin{array}{c}0.001 \\
(0.017)\end{array}$ & $\begin{array}{c}0.031 \\
(0.012)\end{array}$ & $\begin{array}{c}0.066 \\
(0.028)\end{array}$ & $\begin{array}{c}0.066 \\
(0.028)\end{array}$ & $\begin{array}{c}0.060 \\
(0.028)\end{array}$ \\
\hline Year FE & Yes & Yes & Yes & Yes & Yes & Yes & Yes \\
\hline Subject FE & No & Yes & Yes & Yes & No & Yes & Yes \\
\hline Schools' and Students' Characteristics & No & No & Yes & Yes & No & No & Yes \\
\hline School FE & No & No & No & Yes & No & No & No \\
\hline Number of Students & 10,249 & 10,249 & 10,190 & 10,190 & 39,915 & 39,915 & 39,852 \\
\hline Number of Schools & 82 & 82 & 82 & 82 & 301 & 301 & 301 \\
\hline Number of Superintendents & 29 & 29 & 29 & 29 & 30 & 30 & 30 \\
\hline
\end{tabular}

Notes : Standard errors in parenthesis are clustered at the superintendent-by-year level. Schools characteristics include number of classes, number of students and the number of schools included in a superintendent's cluster. Students' characteristics include gender, ethnic origin, parents' education, number of siblings and immigrant status. All schools are in the jewish nonreligious primary school system. Sample includes stacked math, hebrew and english tests scores. Test scores and superintendents value added are standardized with 0 mean and unit sd. 
Table 7: The Effect of Superintendent Value Added on Tests Z-Scores

\begin{tabular}{|c|c|c|c|c|}
\hline & \multicolumn{2}{|c|}{ Bayes Corrected Estimates } & \multicolumn{2}{|c|}{$\begin{array}{c}\text { Two-Step Bootstrapped } \\
\text { Standard Errors }\end{array}$} \\
\hline & $\begin{array}{c}\text { Method I } \\
\text { (1) } \\
\end{array}$ & $\begin{array}{c}\text { Method II } \\
\text { (2) } \\
\end{array}$ & $\begin{array}{c}\text { Method I } \\
\text { (3) } \\
\end{array}$ & $\begin{array}{c}\text { Method II } \\
\text { (4) }\end{array}$ \\
\hline \multicolumn{5}{|l|}{ A. Full Sample } \\
\hline Students' Sample Regressions & $\begin{array}{c}0.038 \\
(0.017)\end{array}$ & $\begin{array}{c}0.050 \\
(0.034)\end{array}$ & $\begin{array}{c}0.040 \\
(0.015)\end{array}$ & $\begin{array}{c}0.051 \\
(0.018)\end{array}$ \\
\hline \multicolumn{5}{|l|}{ B. Female Superintendents Sample } \\
\hline Students' Sample Regressions & $\begin{array}{c}0.053 \\
(0.012)\end{array}$ & $\begin{array}{c}0.052 \\
(0.036)\end{array}$ & $\begin{array}{c}0.053 \\
(0.017)\end{array}$ & $\begin{array}{c}0.053 \\
(0.018)\end{array}$ \\
\hline \multicolumn{5}{|c|}{ C. Full Sample - By Parental Education (Student Level) } \\
\hline Below Median Father's Years of Schooling & $\begin{array}{c}0.043 \\
(0.029)\end{array}$ & $\begin{array}{c}0.049 \\
(0.038)\end{array}$ & $\begin{array}{c}0.047 \\
(0.022)\end{array}$ & $\begin{array}{c}0.050 \\
(0.019)\end{array}$ \\
\hline Above Median Father's Years of Schooling & $\begin{array}{c}0.032 \\
(0.013)\end{array}$ & $\begin{array}{c}0.063 \\
(0.029)\end{array}$ & $\begin{array}{c}0.031 \\
(0.020)\end{array}$ & $\begin{array}{c}0.060 \\
(0.018)\end{array}$ \\
\hline Year FE & Yes & Yes & Yes & Yes \\
\hline Subject FE & Yes & Yes & Yes & Yes \\
\hline Schools' and Students' Characteristics & Yes & Yes & Yes & Yes \\
\hline School FE & Yes & No & Yes & No \\
\hline Number of Students & 10,190 & 39,852 & 10,190 & 39,852 \\
\hline Number of Schools & 82 & 301 & 82 & 301 \\
\hline Number of Superintendents & 29 & 30 & 29 & 30 \\
\hline
\end{tabular}

Notes: Standard errors used to calculate bayes estimates at the VA estimation regression are clustered at the superintendent level. Standard errors in columns (1)-(2) are clustered at the superintendent-by-year level. Standard errors in columns (3)-(4) bootstrapped using the following two-step procedure: First, for each school in each period, we draw a random sample of students with replacement (In method I we draw a random sample of schools with replacement). The VA estimation regression is estimated on this random sample, and the corresponding VA estimates are obtained. The second stage regression is then estimated on a random sample of students with replacement. This process is repeated a 1,000 times, and the bootstrap standard errors are computed using the sample of these 1,000 second-stage coefficient estimates. Schools characteristics include number of classes, number of students and the number of schools under the school's superintendent. Students' characteristics include gender, ethnic origin, parents' education, number of siblings and immigrant status. All schools are in the jewish non-religious primary school system. Sample includes stacked math, hebrew and english tests scores. Test scores and superintendents value added are standardized with 0 mean and unit sd. 


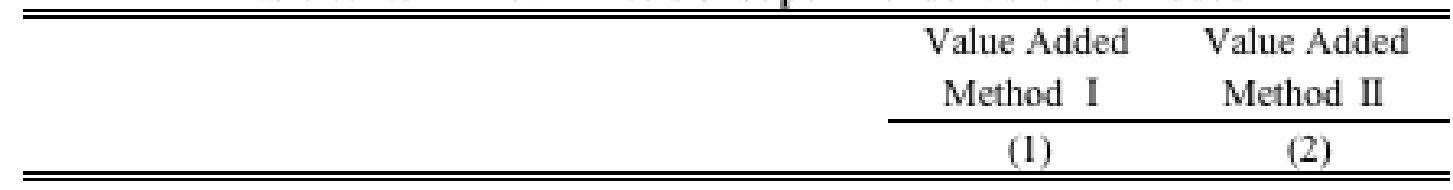

\section{A. Median}

Above Median VA

0.065

0.082

(0.036)

(0.036)

\section{B. Quartiles}

$\begin{array}{lcc}\text { 2nd VA Quartile } & 0.031 & 0.080 \\ & (0.038) & (0.051) \\ \text { 3rd VA Quartile } & & \\ & 0.055 & 0.099 \\ & (0.039) & (0.056) \\ \text { 4th VA Quartile } & & \\ & 0.130 & 0.135 \\ & (0.045) & (0.057)\end{array}$

Year FE

$\begin{array}{cc}\text { Yes } & \text { Yes } \\ \text { Yes } & \text { Yes } \\ \text { Yes } & \text { Yes } \\ \text { Yes } & \text { No }\end{array}$

Subject FE

Schools' and Students' Characteristics

School FE

$\begin{array}{cc}10,190 & 39,852 \\ 82 & 301 \\ 29 & 30\end{array}$

Number of Students

30

Number of Superintendents

Notes: Standard errors in parenthesis are clustered at the superintendent-by-year level. Schools characteristics include number of classes, number of students and the number of schools included in the superintendent's cluster. Students' characteristics include gender, ethnic origin, parents' education, number of siblings and immigrant status. All schools are in the jewish non-religious primary school system. Sample includes stacked math, hebrew and english tests scores. Test scores and superintendents VA are standardized with 0 mean and unit sd. 
Table 9: The Effect of Superintendent Value Added I on Tests Scores - Middle Schools Sample

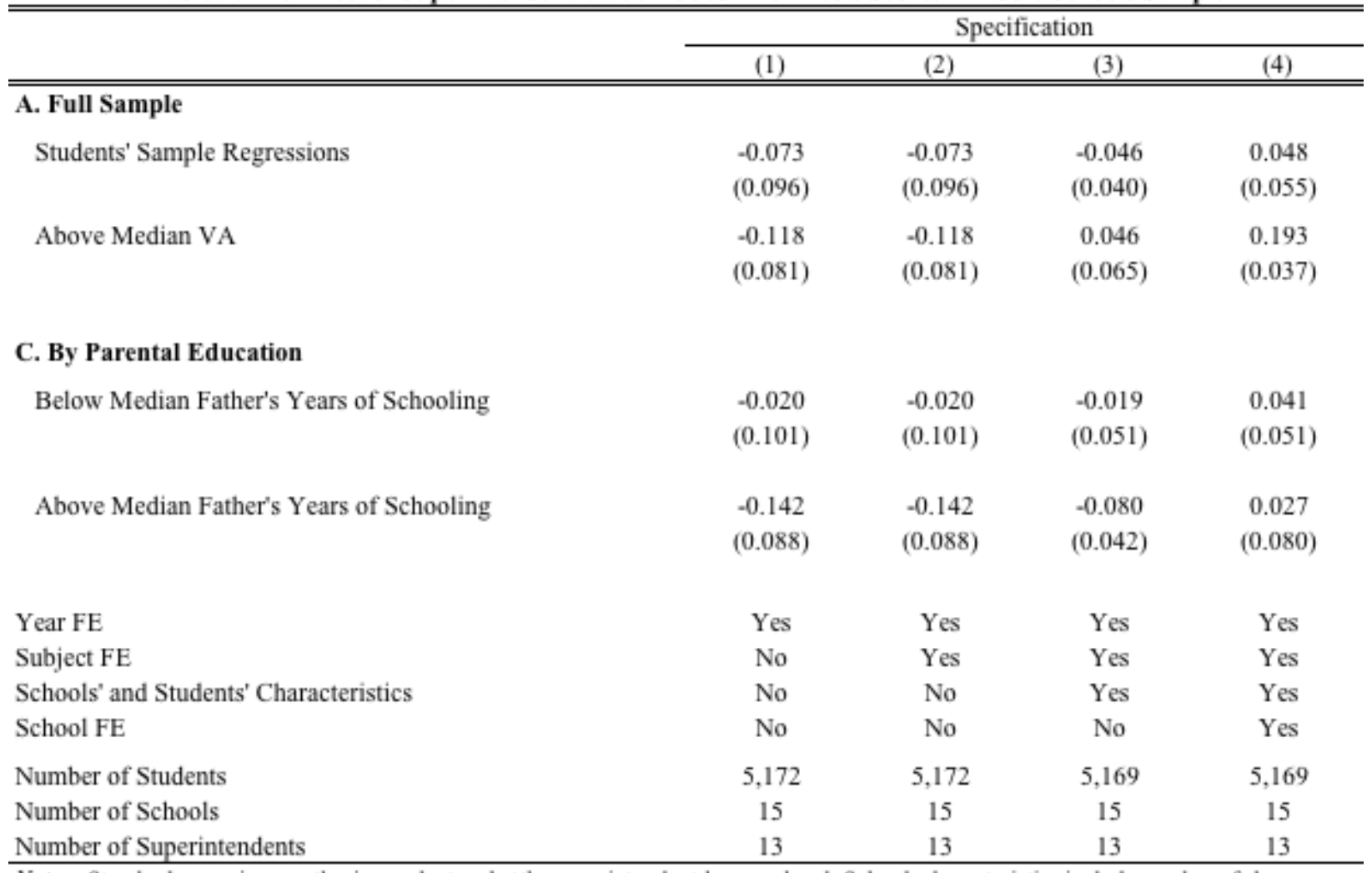

Notes : Standard errors in parenthesis are clustered at the superintendent-by-year level. Schools characteristics include number of classes, number of students and the number of schools included in a superintendent's cluster. Students' characteristics include gender, ethnic origin, parents' education, number of siblings and immigrant status. All schools are in the jewish non-religious middle school system. Sample includes stacked math, hebrew and english tests scores. Test scores and superintendents value added are standardized with 0 mean and unit sd. 
Table 10: The Effect of Superintendent Value Added I on Working Procedures and School Resources

\begin{tabular}{|c|c|c|c|c|}
\hline & \multirow{2}{*}{$\begin{array}{c}\text { Mean } \\
\text { (1) } \\
\end{array}$} & \multicolumn{3}{|c|}{ Specification } \\
\hline & & $(2)$ & (3) & (4) \\
\hline \multicolumn{5}{|c|}{ A. School's Priorities and Working Procedures (Rank 1-6) } \\
\hline Clearly Defined Priorities & $\begin{array}{c}5.419 \\
(0.462)\end{array}$ & $\begin{array}{c}0.231 \\
(0.122)\end{array}$ & $\begin{array}{c}0.199 \\
(0.101)\end{array}$ & $\begin{array}{c}0.230 \\
(0.103)\end{array}$ \\
\hline Teachers Involved in Setting School Priorities & $\begin{array}{c}4.657 \\
(0.635)\end{array}$ & $\begin{array}{c}0.095 \\
(0.085)\end{array}$ & $\begin{array}{c}0.107 \\
(0.085)\end{array}$ & $\begin{array}{c}0.330 \\
(0.173)\end{array}$ \\
\hline Clearly Defined Working Procedures & $\begin{array}{c}5.461 \\
(0.494)\end{array}$ & $\begin{array}{c}0.179 \\
(0.141)\end{array}$ & $\begin{array}{c}0.149 \\
(0.122)\end{array}$ & $\begin{array}{c}0.102 \\
(0.121)\end{array}$ \\
\hline Average Effect & $\begin{array}{c}5.229 \\
(0.456)\end{array}$ & $\begin{array}{c}0.159 \\
(0.103)\end{array}$ & $\begin{array}{c}0.145 \\
(0.087)\end{array}$ & $\begin{array}{c}0.144 \\
(0.115)\end{array}$ \\
\hline \multicolumn{5}{|l|}{ B. School's Resources (Weekly Instruction Hours) } \\
\hline Instruction Budget per Class & $\begin{array}{l}44.981 \\
(6.364)\end{array}$ & $\begin{array}{l}-0.048 \\
(0.143)\end{array}$ & $\begin{array}{l}-0.090 \\
(0.055)\end{array}$ & $\begin{array}{l}-0.015 \\
(0.055)\end{array}$ \\
\hline Length of the School Week & $\begin{array}{l}33.931 \\
(3.062)\end{array}$ & $\begin{array}{l}-0.057 \\
(0.131)\end{array}$ & $\begin{array}{l}-0.024 \\
(0.061)\end{array}$ & $\begin{array}{l}-0.082 \\
(0.047)\end{array}$ \\
\hline Instruction Hours of Math, Science and English & $\begin{array}{r}14.186 \\
(1.937)\end{array}$ & $\begin{array}{l}-0.012 \\
(0.142)\end{array}$ & $\begin{array}{l}-0.017 \\
(0.098)\end{array}$ & $\begin{array}{l}-0.038 \\
(0.088)\end{array}$ \\
\hline Average Effect & $\begin{array}{l}31.032 \\
(3.397)\end{array}$ & $\begin{array}{l}-0.039 \\
(0.134)\end{array}$ & $\begin{array}{l}-0.044 \\
(0.057)\end{array}$ & $\begin{array}{l}-0.045 \\
(0.046)\end{array}$ \\
\hline \multicolumn{5}{|c|}{ C. Students' Time Allocated to Homework (Weekly Hours) } \\
\hline Math & $\begin{array}{c}2.960 \\
(1.563)\end{array}$ & $\begin{array}{c}0.010 \\
(0.033)\end{array}$ & $\begin{array}{c}0.014 \\
(0.026)\end{array}$ & $\begin{array}{l}-0.029 \\
(0.023)\end{array}$ \\
\hline English & $\begin{array}{c}2.763 \\
(1.622)\end{array}$ & $\begin{array}{l}-0.037 \\
(0.044)\end{array}$ & $\begin{array}{l}-0.030 \\
(0.036)\end{array}$ & $\begin{array}{l}-0.010 \\
(0.030)\end{array}$ \\
\hline Hebrew & $\begin{array}{c}2.264 \\
(1.521)\end{array}$ & $\begin{array}{c}0.036 \\
(0.032)\end{array}$ & $\begin{array}{c}0.057 \\
(0.024)\end{array}$ & $\begin{array}{l}-0.012 \\
(0.031)\end{array}$ \\
\hline Total & $\begin{array}{c}8.002 \\
(3.957)\end{array}$ & $\begin{array}{c}0.011 \\
(0.093)\end{array}$ & $\begin{array}{c}0.045 \\
(0.062)\end{array}$ & $\begin{array}{l}-0.055 \\
(0.071)\end{array}$ \\
\hline Year FE & & Yes & Yes & Yes \\
\hline Student and School Characteristics & & No & Yes & Yes \\
\hline School FE & & No & No & Yes \\
\hline Number of Schools & 82 & 82 & 82 & 82 \\
\hline Number of Superintendents & 29 & 29 & 29 & 29 \\
\hline
\end{tabular}

Notes: In column (1) standard deviations are presented in parenthesis. In columns (2)-(5) standard errors in parenthesis are adjusted for supintendent level clustering. An average effect is an equally weighted average of the rest of its panel's questions' values in column (1), and zscores in columns (2)-(4). Panel A is drawn from teachers' survey data and non-index variables originally take value of 0 or 1 . Panel B is drawn from administrative data on school funding, and is only available for 71 schools (and 27 superintendents). Panel C is drawn from students' survey data. Schools characteristics include number of classes, number of students and the number of schools included in the superintendent's cluster. Students' characteristics include gender, ethnic origin, parents' education, number of siblings and immigrant status. All schools are in the jewish non-religious primary school system. Superintendents value added is standardized with 0 mean and unit sd. Outcomes and students' characteristics are school means. The dependent variable is a standardized transformation (mean zero, unit standard deviation) of the raw variable. 
Table 11: The Effect of Superintendent Value Added I on School Environment and Climate

\begin{tabular}{|c|c|c|c|c|}
\hline & \multirow{2}{*}{$\begin{array}{c}\text { Mean } \\
(1) \\
\end{array}$} & \multicolumn{3}{|c|}{ Specification } \\
\hline & & (2) & (3) & (4) \\
\hline \multicolumn{5}{|l|}{ A. School Climate and Norms Indicators $(0 / 1)$} \\
\hline School Evaluates its Environment, Climate and Discipline & $\begin{array}{c}0.707 \\
(0.456)\end{array}$ & $\begin{array}{c}0.267 \\
(0.070)\end{array}$ & $\begin{array}{c}0.264 \\
(0.093)\end{array}$ & $\begin{array}{c}0.250 \\
(0.074)\end{array}$ \\
\hline Interventions Related to School Environment and Discipline & $\begin{array}{c}0.291 \\
(0.456)\end{array}$ & $\begin{array}{c}0.097 \\
(0.075)\end{array}$ & $\begin{array}{c}0.335 \\
(0.099)\end{array}$ & $\begin{array}{c}0.493 \\
(0.224)\end{array}$ \\
\hline Average Effect & $\begin{array}{c}0.549 \\
(0.385)\end{array}$ & $\begin{array}{c}0.203 \\
(0.054)\end{array}$ & $\begin{array}{c}0.253 \\
(0.070)\end{array}$ & $\begin{array}{c}0.262 \\
(0.077)\end{array}$ \\
\hline \multicolumn{5}{|l|}{ B. Violence in School based on Students' Assessment (Rank 1-6) } \\
\hline "There are many fights among students in my classroom" & $\begin{array}{c}3.593 \\
(1.497)\end{array}$ & $\begin{array}{l}-0.040 \\
(0.023)\end{array}$ & $\begin{array}{l}-0.042 \\
(0.022)\end{array}$ & $\begin{array}{l}-0.035 \\
(0.018)\end{array}$ \\
\hline "This year I was involved in many fights" & $\begin{array}{c}1.941 \\
(1.389)\end{array}$ & $\begin{array}{c}0.014 \\
(0.021)\end{array}$ & $\begin{array}{c}0.006 \\
(0.016)\end{array}$ & $\begin{array}{c}-0.034 \\
(0.016)\end{array}$ \\
\hline "Sometimes I'm scared to go to school because there are violent students" & $\begin{array}{c}1.938 \\
(1.483)\end{array}$ & $\begin{array}{l}-0.012 \\
(0.019)\end{array}$ & $\begin{array}{c}0.002 \\
(0.013)\end{array}$ & $\begin{array}{l}-0.024 \\
(0.012)\end{array}$ \\
\hline Average Effect & $\begin{array}{c}2.492 \\
(1.031)\end{array}$ & $\begin{array}{l}-0.013 \\
(0.014)\end{array}$ & $\begin{array}{l}-0.012 \\
(0.010)\end{array}$ & $\begin{array}{l}-0.033 \\
(0.012)\end{array}$ \\
\hline \multicolumn{5}{|l|}{ C. Students' Satisfcation (Rank 1-6) } \\
\hline "There's someone in the teaching staff I can turn to" & $\begin{array}{c}5.091 \\
(1.324)\end{array}$ & $\begin{array}{c}0.012 \\
(0.017)\end{array}$ & $\begin{array}{c}0.007 \\
(0.016)\end{array}$ & $\begin{array}{c}0.036 \\
(0.008)\end{array}$ \\
\hline "I am staisfied in school" & $\begin{array}{c}5.252 \\
(1.147)\end{array}$ & $\begin{array}{c}0.003 \\
(0.019)\end{array}$ & $\begin{array}{c}0.010 \\
(0.017)\end{array}$ & $\begin{array}{c}0.011 \\
(0.017)\end{array}$ \\
\hline "I'm socially staisfied in school" & $\begin{array}{c}5.246 \\
(1.195)\end{array}$ & $\begin{array}{l}-0.001 \\
(0.009)\end{array}$ & $\begin{array}{l}-0.002 \\
(0.009)\end{array}$ & $\begin{array}{c}0.004 \\
(0.013)\end{array}$ \\
\hline Average Effect & $\begin{array}{c}5.193 \\
(0.926)\end{array}$ & $\begin{array}{c}0.005 \\
(0.017)\end{array}$ & $\begin{array}{c}0.006 \\
(0.016)\end{array}$ & $\begin{array}{c}0.019 \\
(0.014)\end{array}$ \\
\hline Year FE & & Yes & Yes & Yes \\
\hline Student and School Characteriscs & & No & Yes & Yes \\
\hline School FE & & No & No & Yes \\
\hline Number of Schools & 82 & 82 & 82 & 82 \\
\hline Number of Superintendents & 29 & 29 & 29 & 29 \\
\hline
\end{tabular}

Notes: In column (1) standard deviations are presented in parenthesis. In columns (2)-(5) standard errors in parenthesis are adjusted for superintendent level clustering. An average effect is an equally weighted average of the rest of its panel's questions' values in column(1), andzscores in columns (2)-(4) Panel A is drawn from principals' survey data, outcomes and students' characteristics are school means and non-index variables originally take value of 0 or 1 . Panels B and C are drawn from students' survey data, outcomes and students' characteristics are individual level data and non-index variables are on a scale of 1-6. Schools characteristics include number of classes, number of students and the number of schools included in the superintendent's cluster. Student and school characteristics also include share of boys in the class in the violence related dependent variables. Students' characteristics include gender, ethnic origin, parents' education, number of siblings and immigrant status. All schools are in the jewish non-religious primary school system. Superintendents value added is standardized with 0 mean and unit sd. The dependent variable is a standardized transformation (mean zero, unit standard deviation) of the raw variable. 
Table 12: The Effect of Superintendent Value Added I on School Scholastic Programs and Teachers' In and Out of School Training

\begin{tabular}{cccc} 
Mean & \multicolumn{3}{c}{ Specification } \\
\cline { 2 - 4 } (1) & (2) & (3) & (4) \\
\hline
\end{tabular}

\section{A. School has an Academic Program (0/1) in:}

Hebrew

Math

English

Average Effect

$\begin{array}{cccc}0.333 & -0.123 & 0.047 & 0.274 \\ (0.473) & (0.104) & (0.129) & (0.294) \\ 0.265 & -0.220 & -0.063 & -0.116 \\ (0.443) & (0.098) & (0.111) & (0.432) \\ 0.222 & -0.116 & -0.116 & 0.472 \\ (0.418) & (0.100) & (0.147) & (0.297) \\ 0.274 & -0.153 & -0.044 & 0.210 \\ (0.363) & (0.085) & (0.094) & (0.294)\end{array}$

B. Teachers Receive Out of School Training (0/1) in:

Hebrew

$\begin{array}{cccc}0.465 & 0.030 & 0.087 & 0.043 \\ (0.201) & (0.078) & (0.092) & (0.149) \\ 0.372 & 0.096 & 0.096 & 0.021 \\ (0.191) & (0.062) & (0.092) & (0.106)\end{array}$

English

$\begin{array}{llll}0.183 & 0.099 & -0.022 & 0.035\end{array}$

Average Effect

$\begin{array}{llll}(0.259) & (0.150) & (0.113) & (0.083)\end{array}$

$\begin{array}{llll}0.342 & 0.075 & 0.064 & 0.050\end{array}$

$\begin{array}{llll}(0.134) & (0.053) & (0.055) & (0.077)\end{array}$

\section{Teachers Receive In-School Training (0/1) in:}

Hebrew

$\begin{array}{cccc}0.507 & 0.037 & 0.064 & 0.313 \\ (0.259) & (0.084) & (0.079) & (0.120) \\ 0.380 & 0.033 & 0.117 & 0.192 \\ (0.259) & (0.079) & (0.104) & (0.122)\end{array}$

English

$\begin{array}{llll}0.188 & -0.044 & -0.172 & -0.151\end{array}$

Average Effect

$(0.347)$

$(0.080)$

$(0.078)$

$(0.102)$

$\begin{array}{llll}0.358 & -0.008 & -0.005 & 0.024\end{array}$

$\begin{array}{llll}(0.162) & (0.014) & (0.016) & (0.020)\end{array}$

Year FE

Student and School Characteristics

School FE

Number of Schools

Number of Superintendents

Number of Teachers

\begin{tabular}{cccc} 
& Yes & Yes & Yes \\
& No & Yes & Yes \\
& No & No & Yes \\
82 & 82 & 82 & 82 \\
29 & 29 & 29 & 29 \\
2,236 & 2,236 & 2,236 & 2,236 \\
\hline
\end{tabular}

Notes: In column (1) standard deviations are presented in parenthesis. In columns (2)-(5) standard errors in parenthesis are adjusted for supintendent level clustering. An average effect is an equally weighted average of the rest of its panel's questions' values in column (1), and zscores in columns (2)-(4) Both panels are drawn from teachers' survey data and non-index variables originally take value of 0 or 1 . Schools characteristics include number of classes, number of students and the number of schools included in the superintendent's cluster. Students' characteristics include gender, ethnic origin, parents' education, number of siblings and immigrant status. All schools are in the jewish non-religious primary school system. Superintendents value addedis standardized with 0 mean and unit sd. Outcomes and students' characteristics are school means. The dependent variable is a standardized transformation (mean zero, unit standard deviation) of the raw variable. 
Table 13: The Effect of Change of Superintendent on Change of School Principal

\begin{tabular}{|c|c|c|c|c|c|c|c|c|c|}
\hline \multirow{2}{*}{$\begin{array}{c}\text { Years Since Change of } \\
\text { Superintendent } \\
\end{array}$} & \multicolumn{3}{|c|}{ Full Sample Period } & \multirow{2}{*}{$\begin{array}{c}2002-2003 \\
(4) \\
\end{array}$} & \multicolumn{2}{|c|}{ 2003-2004 } & \multicolumn{3}{|c|}{ 2004-2005 } \\
\hline & (1) & (2) & (3) & & (5) & (6) & (7) & $(8)$ & (9) \\
\hline First Year & $\begin{array}{c}-0.044 \\
(0.021)\end{array}$ & & $\begin{array}{c}-0.061 \\
(0.028)\end{array}$ & $\begin{array}{c}0.001 \\
(0.033)\end{array}$ & $\begin{array}{c}-0.049 \\
(0.055)\end{array}$ & & $\begin{array}{c}-0.076 \\
(0.032)\end{array}$ & & \\
\hline Second Year & & $\begin{array}{c}0.091 \\
(0.028)\end{array}$ & $\begin{array}{c}0.081 \\
(0.028)\end{array}$ & & & $\begin{array}{c}0.062 \\
(0.035)\end{array}$ & & $\begin{array}{c}0.139 \\
(0.050)\end{array}$ & \\
\hline Third Year & & & & & & & & & $\begin{array}{c}0.007 \\
(0.033)\end{array}$ \\
\hline
\end{tabular}

\begin{tabular}{|c|c|c|c|c|c|c|c|c|c|}
\hline \multicolumn{10}{|c|}{ Share of Schools Changing } \\
\hline Superintendent & 0.15 & 0.15 & 0.15 & 0.15 & 0.17 & 0.17 & 0.14 & 0.14 & 0.14 \\
\hline Number of Schools & 738 & 721 & 721 & 723 & 721 & 714 & 716 & 708 & 701 \\
\hline
\end{tabular}

Notes: The sample includes schools that changed superintendent once or less throughout the sample period $(\sim 90 \%$ of all schools). Standard errors are presented in parenthesis. All

schools are in the jewish non-religious primary school system. In column 4 the change of school principal is between 2002-2003. In columns 5-6 the change in school principal is between 2003-2004. In columns 7-9 the change in school principal is between 2004-2005. 


\section{Figure 1: Superintendents' Turnover: Central District 2004-05}

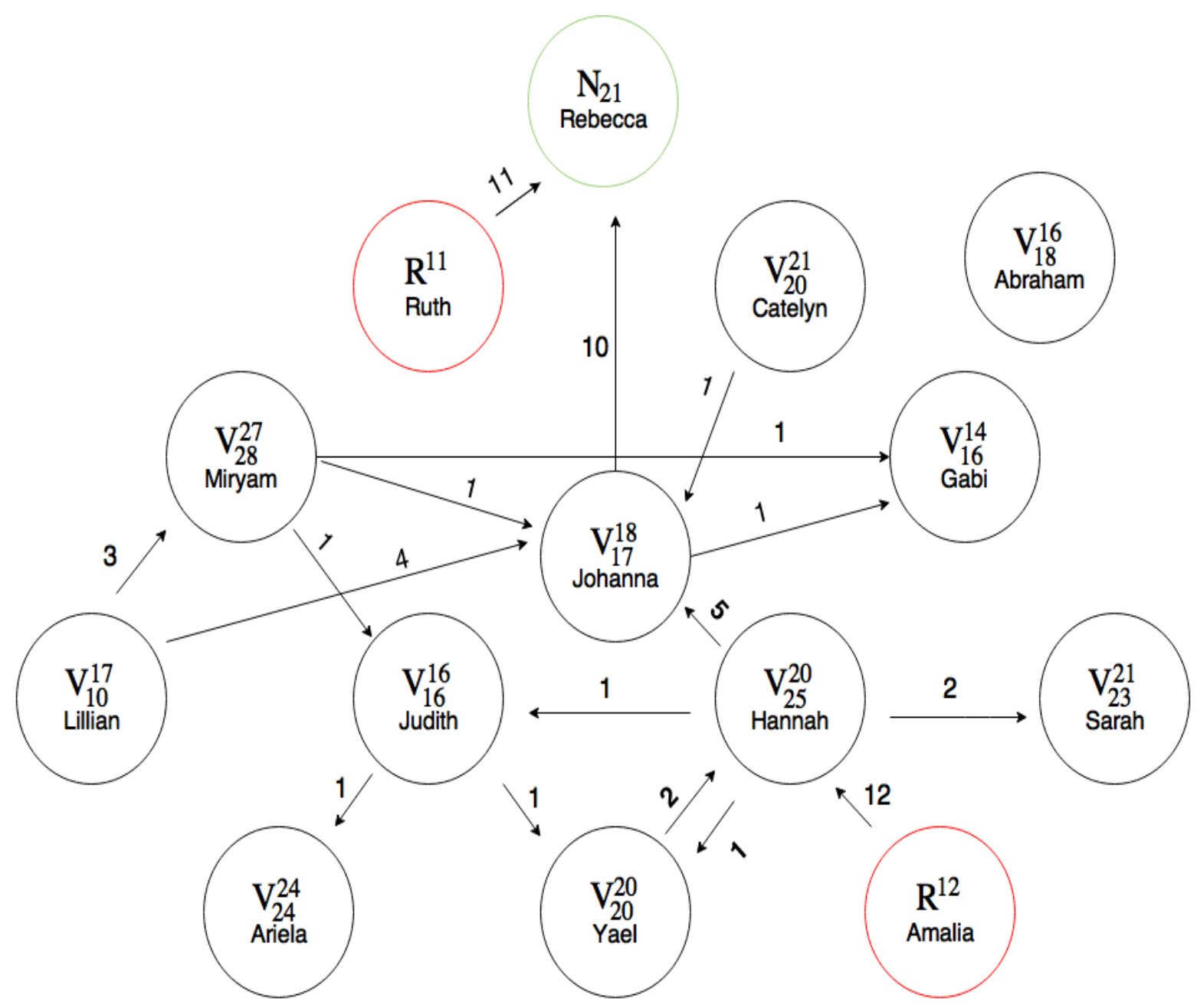

Notes: One of Miryam's 2005 schools is new. Two of Abraham's 2005 schools are new. One of Johanna's 2004 schools closed at the end of the year. One of Ariela's 2004 schools closed at the end of the year. 

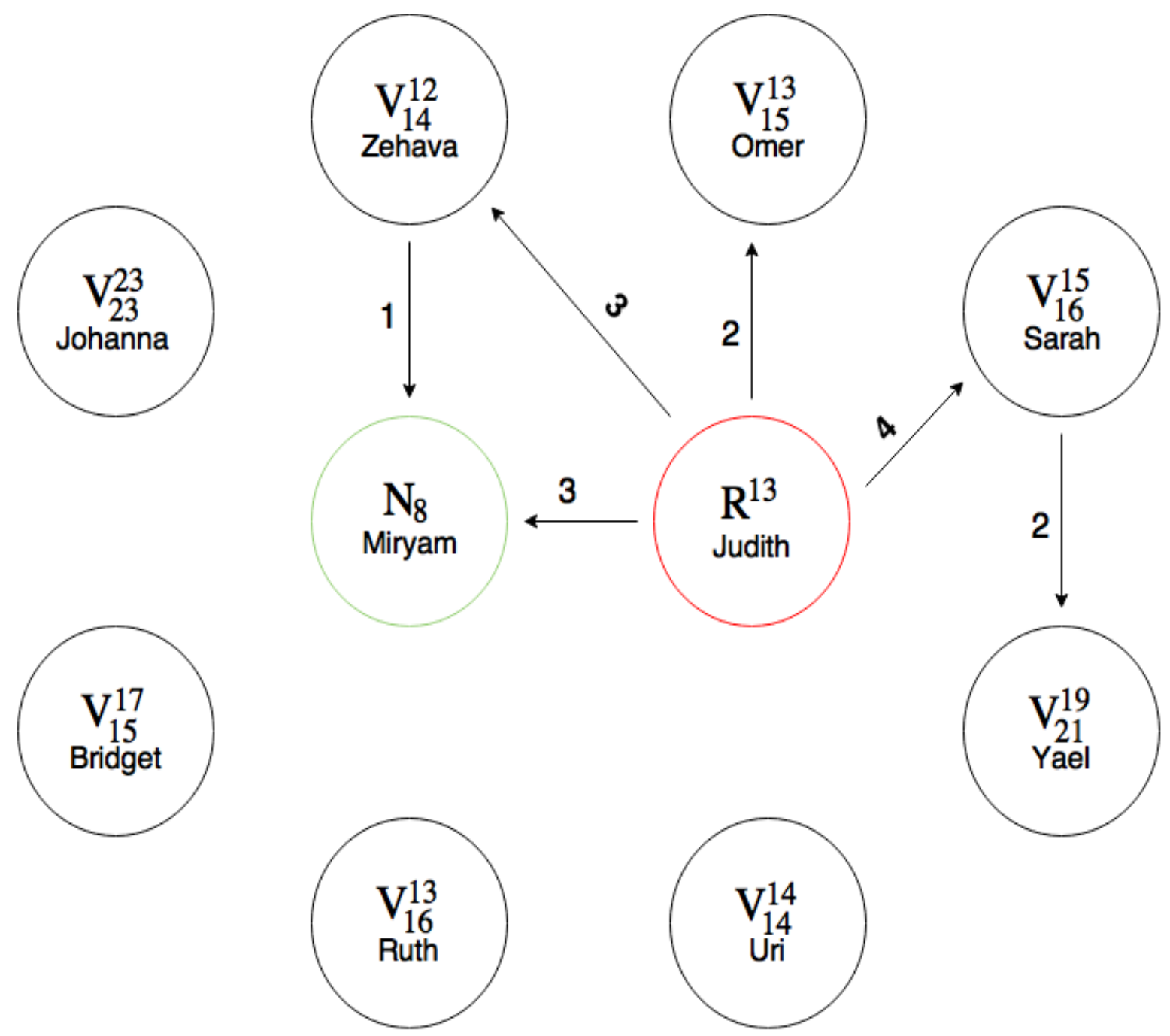

Notes: Miryam had one middle school in 2002 and 4 middle schools in 2003. Uri had 2 middle schools in both years. One of Sarah's 2002 schools closed at the end of the year. Bridget had one middle school in 2002 and one of her 2002 schools closed at the end of the year. Ruth had 5 middle schools in 2002 and 8 middle schools in 2003. 


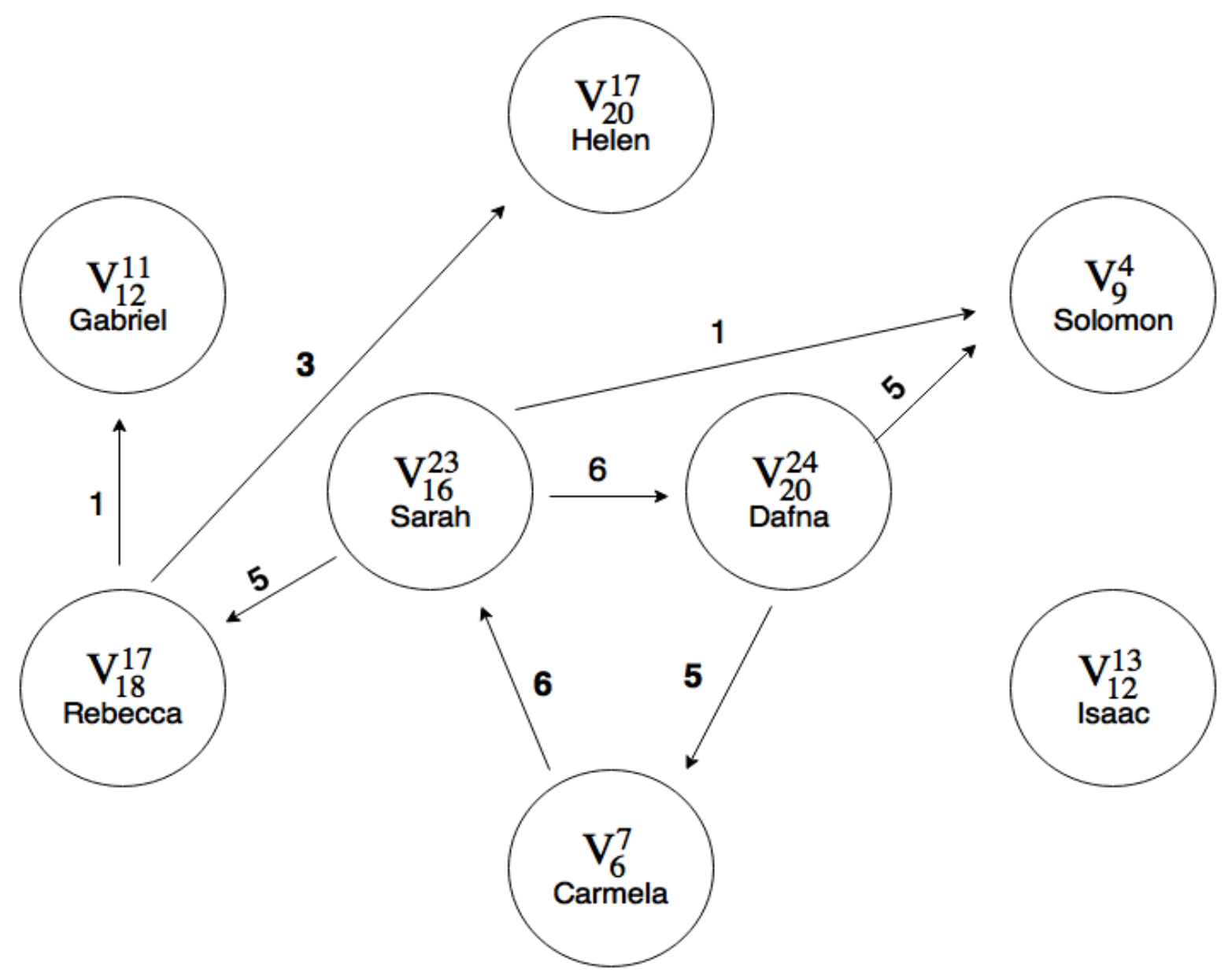

Notes: One of Sarah's 2003 schools closed at the end of the year. Isaac had 6 middle schools in 2003 and 5 middle schools in 2004. Solomon had one Arabic school in 2003 and none in 2004. 
Figure 4: Distribution of Superintendents' Number of Schools

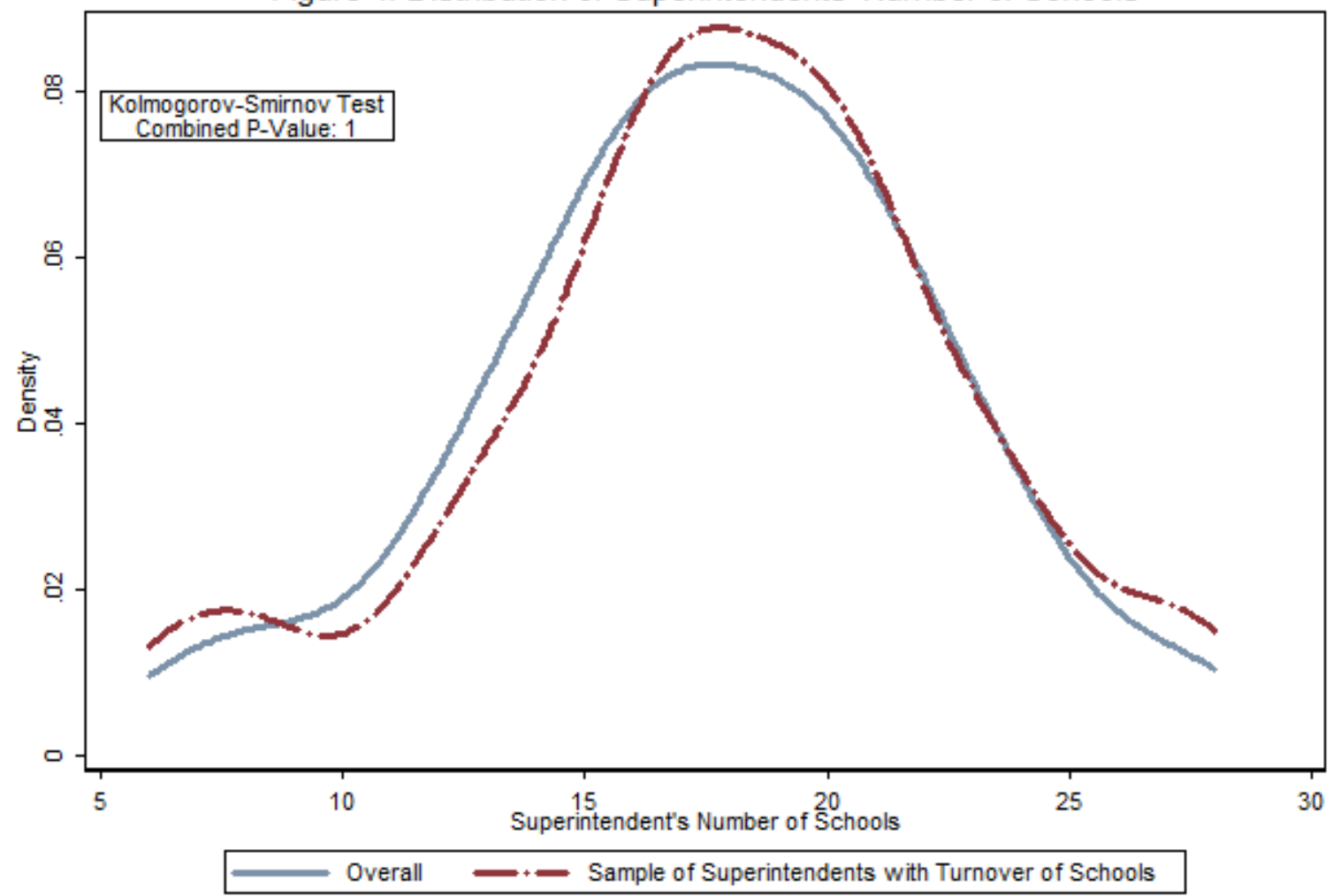


Figure 5: Distribution of Superintendents' Number of Schools in Single and Multi-Superintendent Municipalities

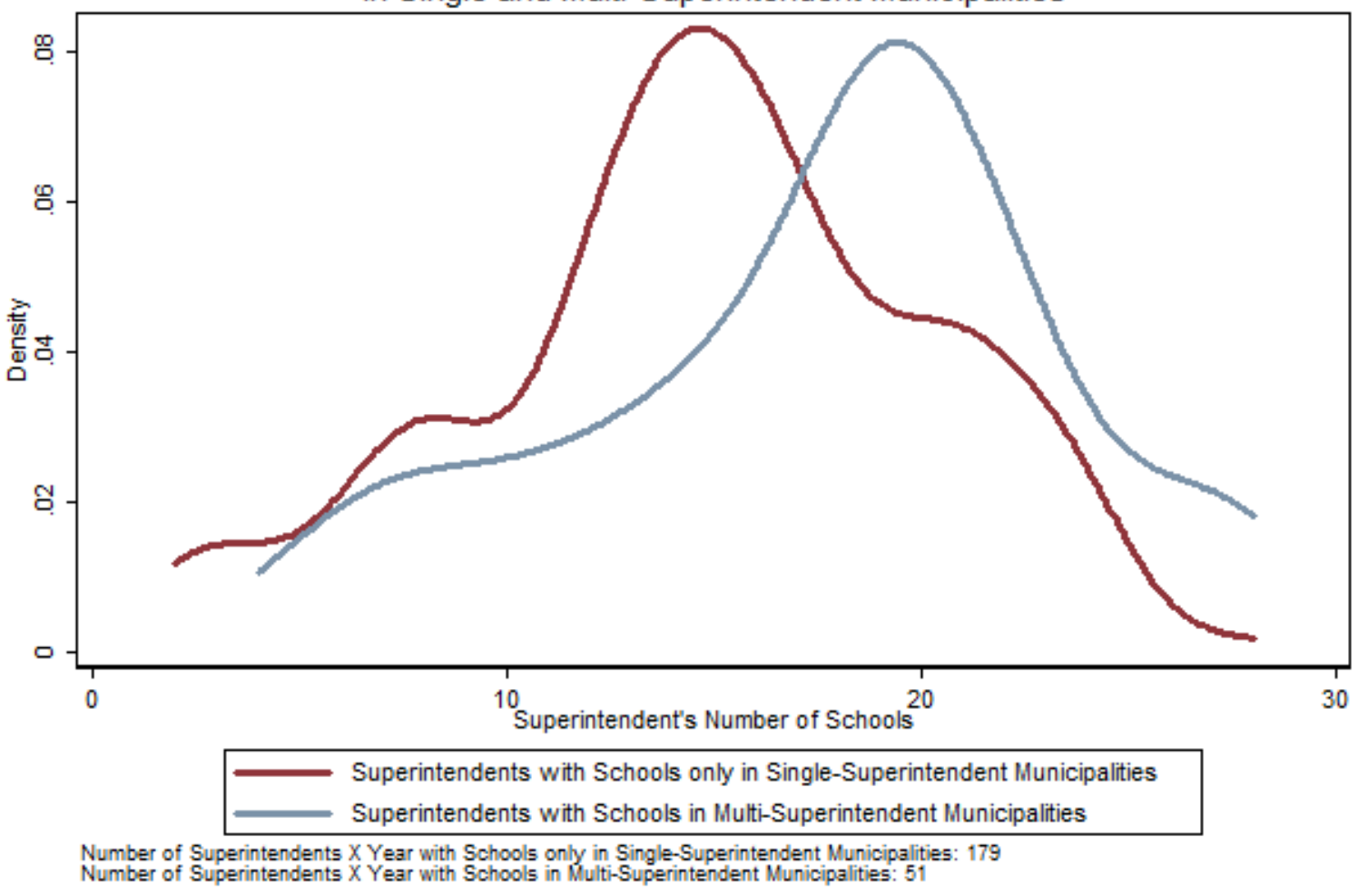


Figure 6: Distribution of Superintendents Value Added I by Period

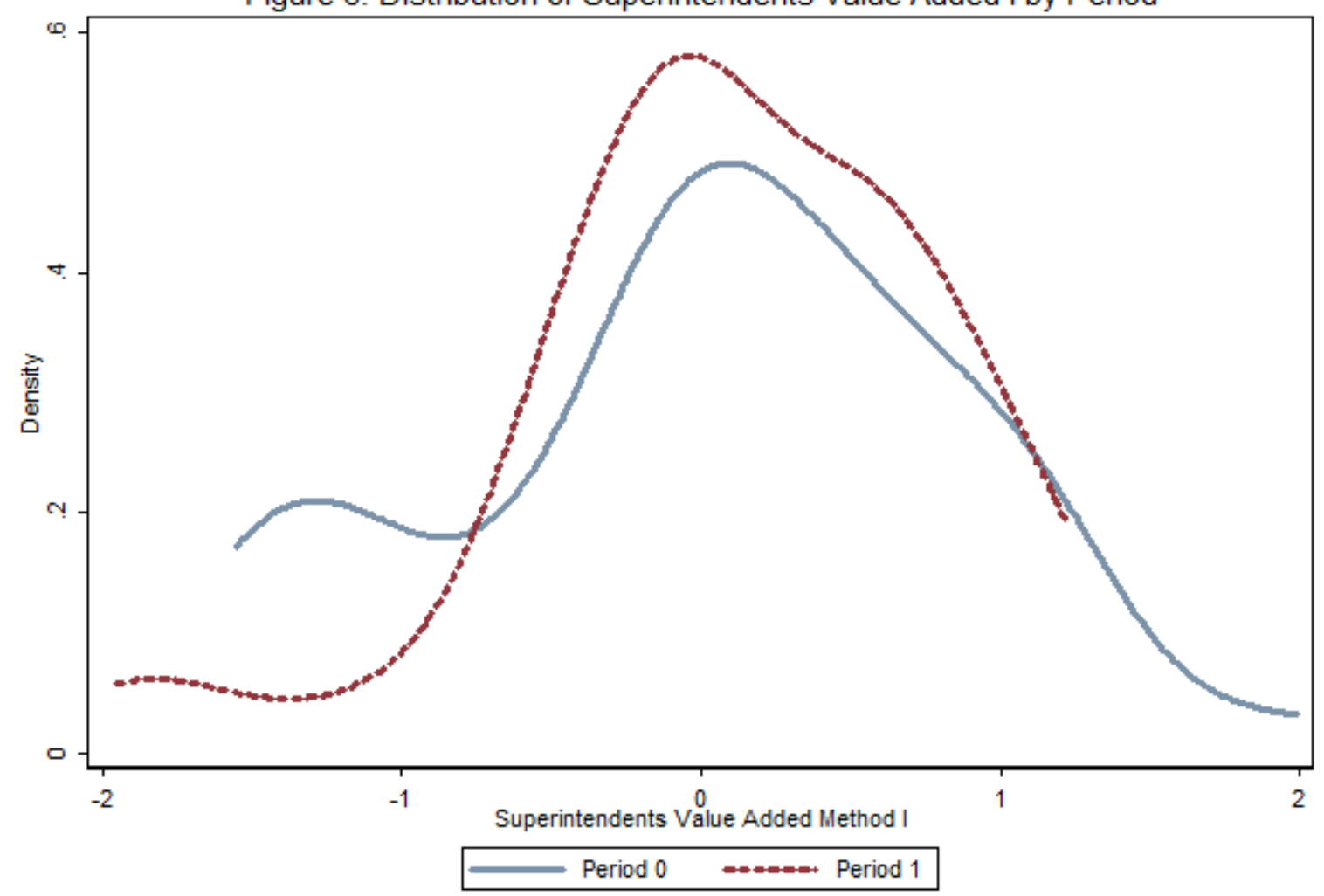


Figure 7: Distribution of Superintendents Value Added I

with Different Controls for Lagged Test Scores

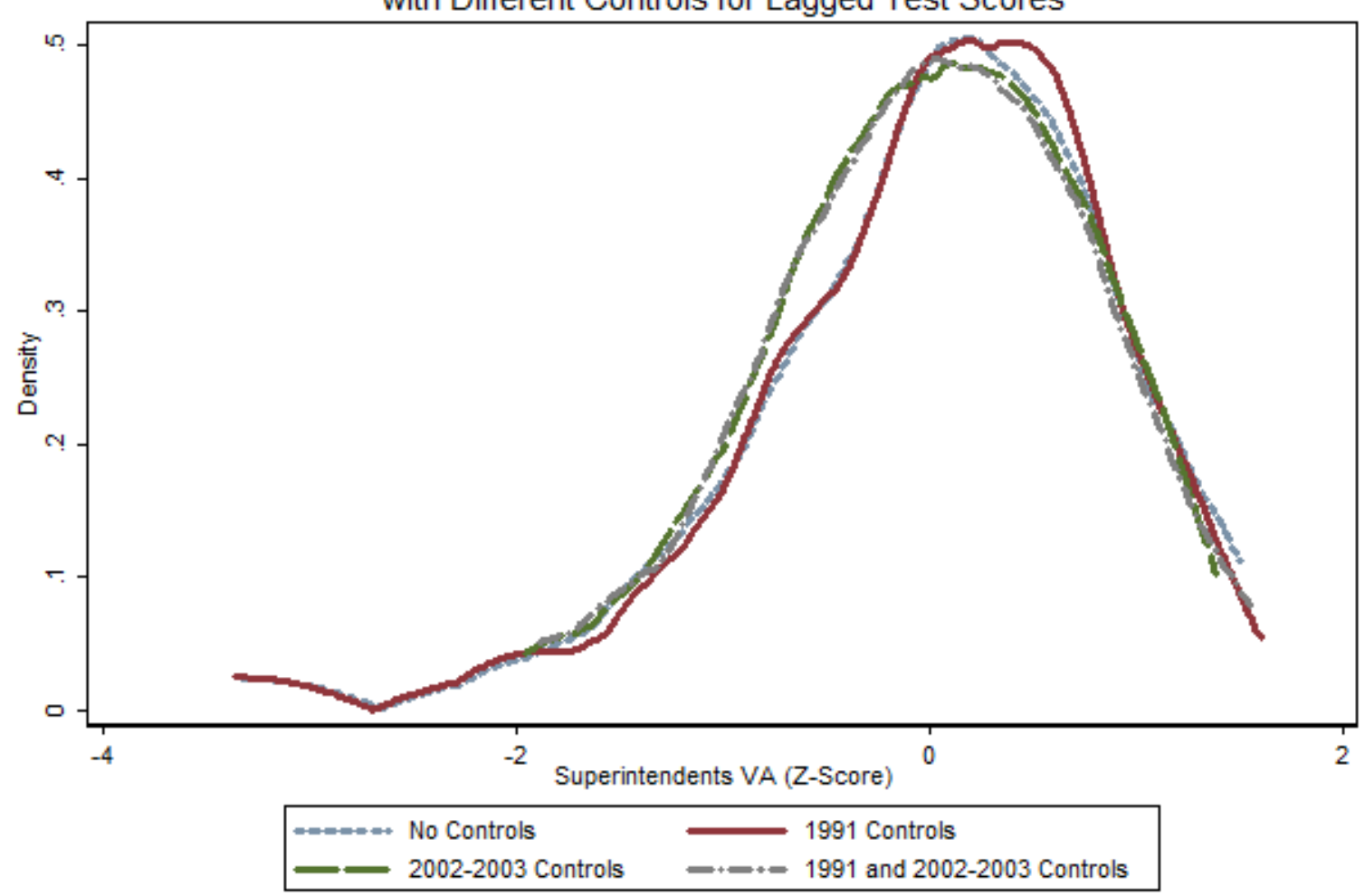


Figure 8: Distribution of Superintendents Value Added II

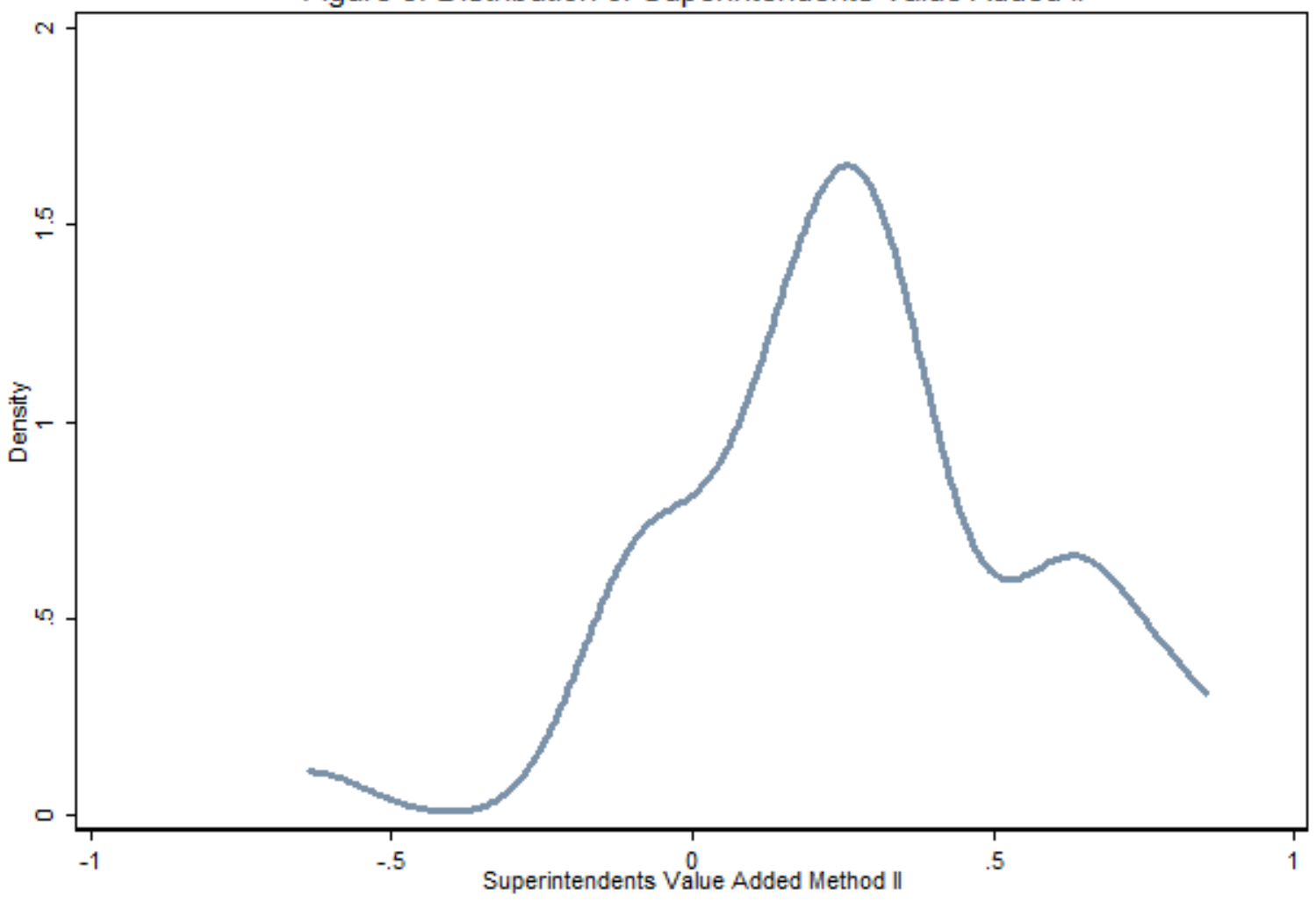


Map 1: Central District 2005

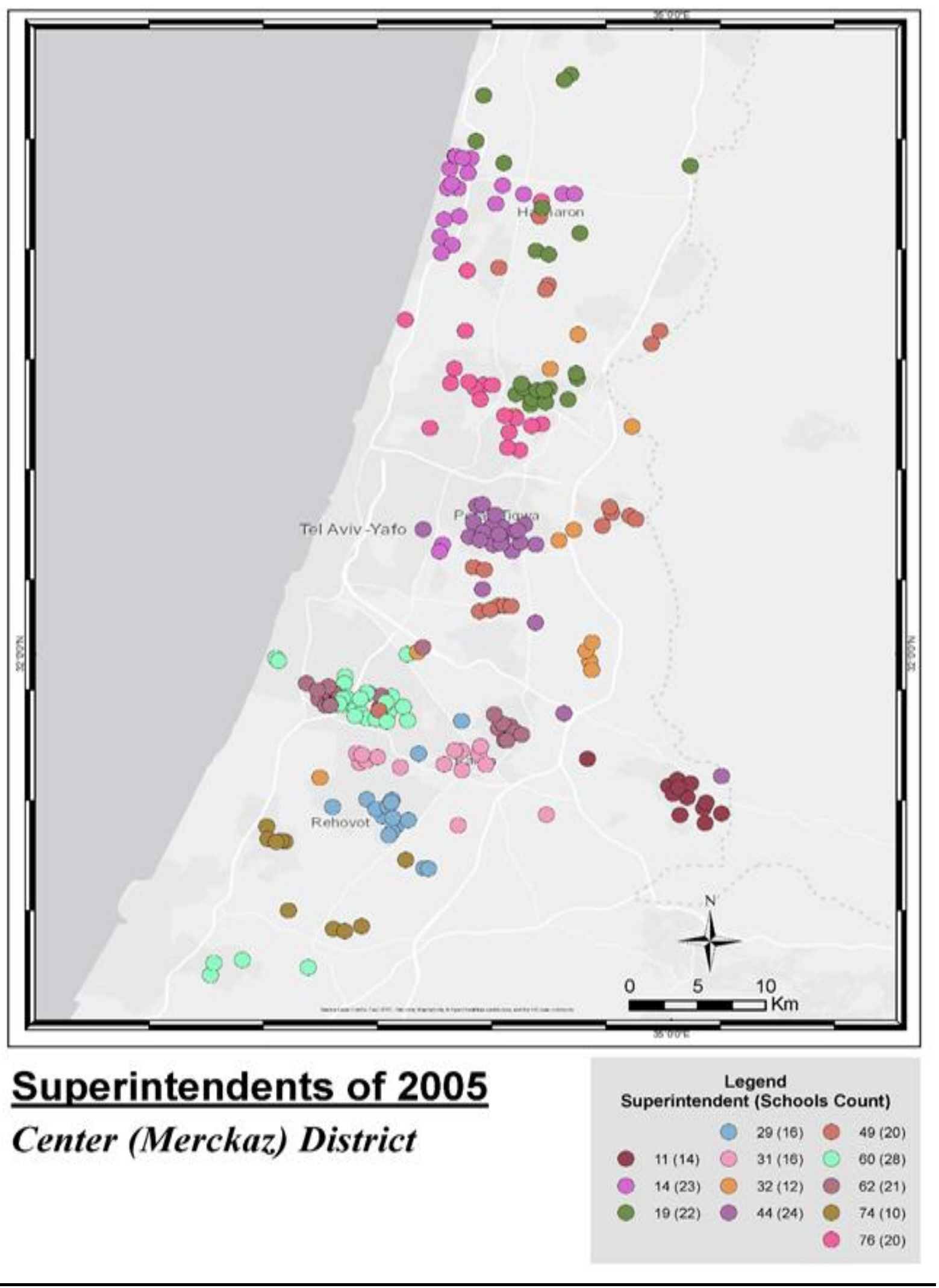


Map 2: Tel Aviv District 2005

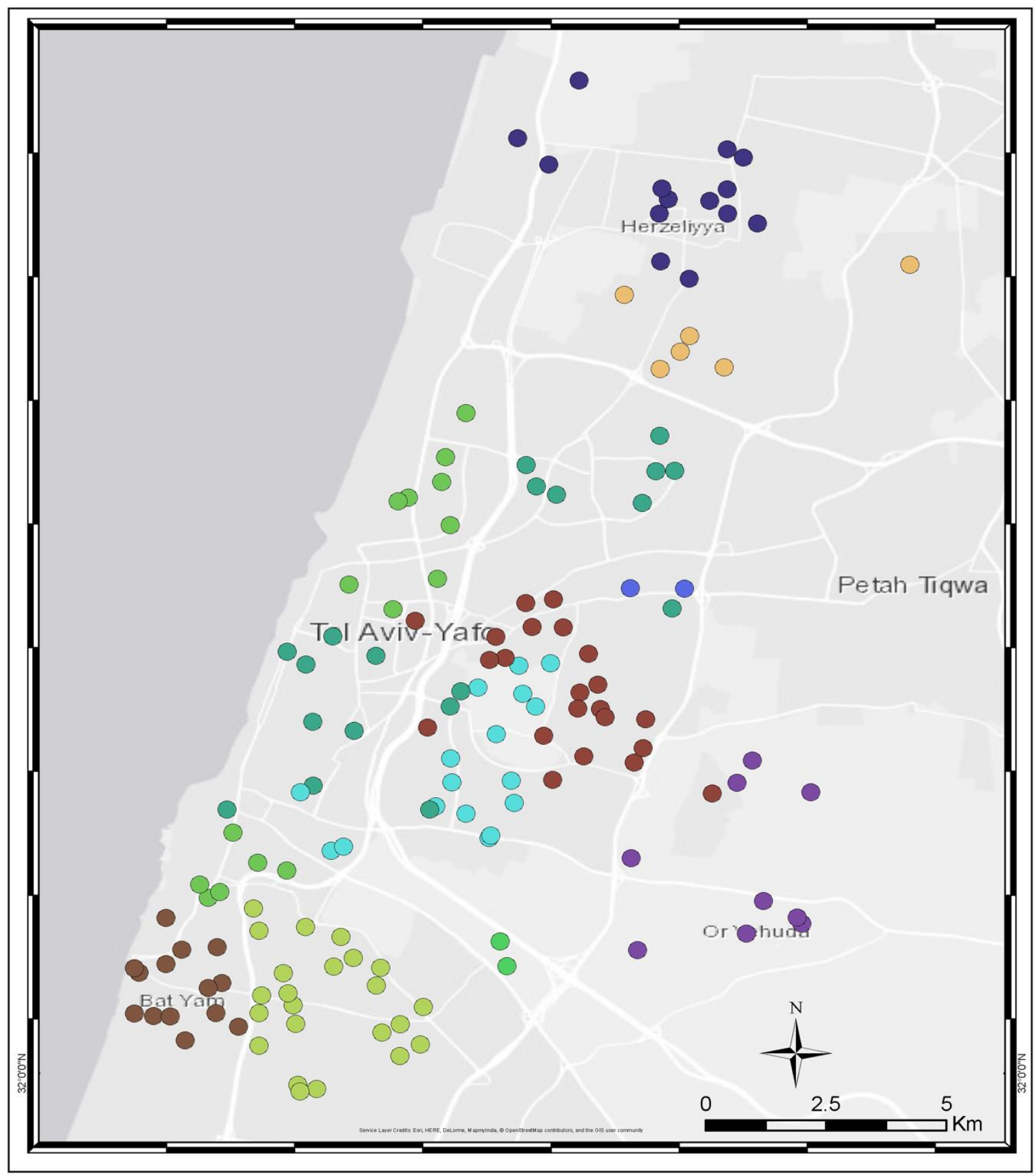

\section{Superintendents of 2005}

Tel Aviv District

Legend

Superintendent (Schools Count)

$9(9) \bigcirc 45(2) \bigcirc 69(2)$

$30(6) \bigcirc 47(15) \bigcirc 70(22)$

$33(23) \bigcirc 63(14) \bigcirc 75(19)$

$43(14) \bigcirc 66(17)$ 
Map 3: South District 2005

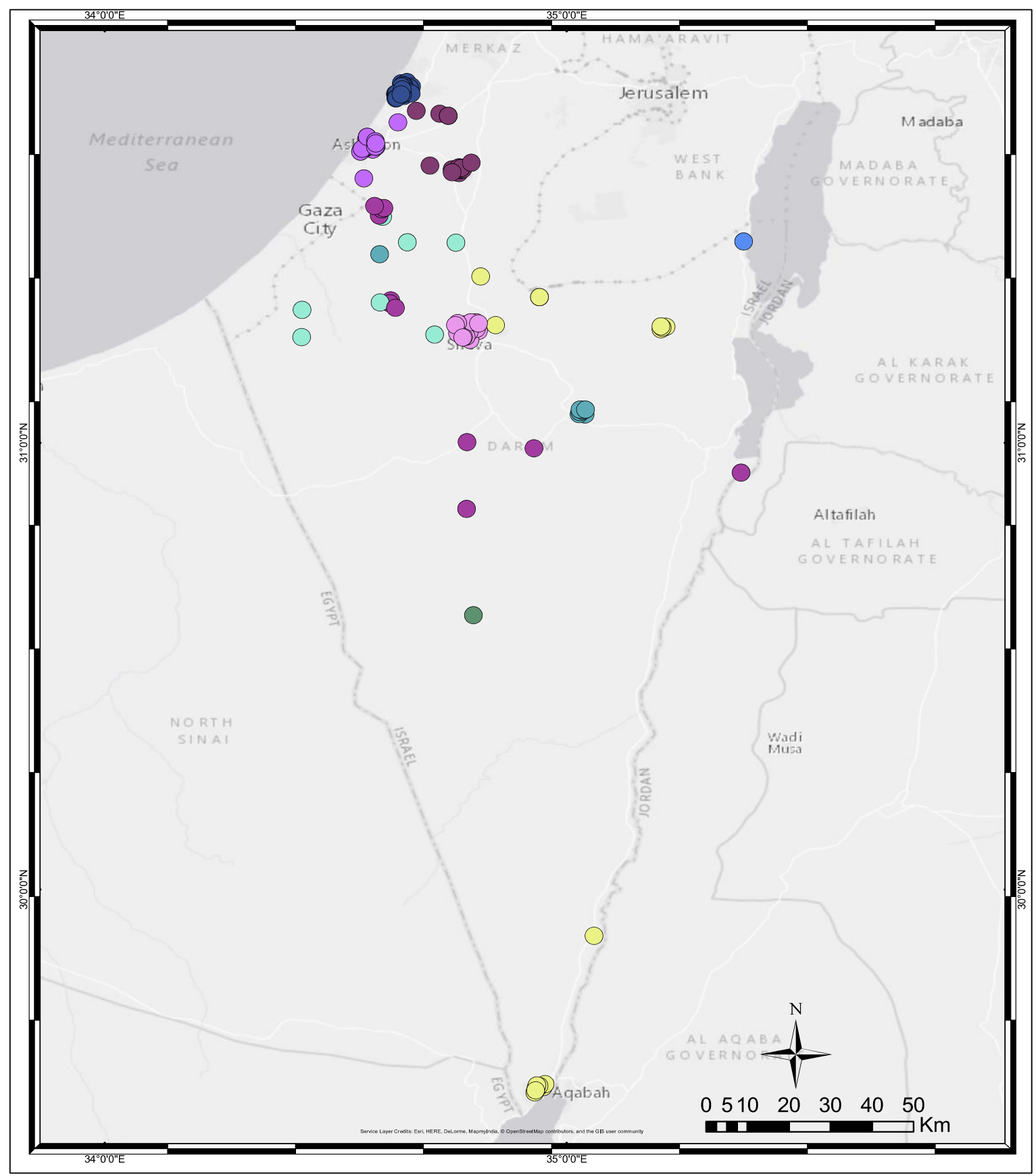

\section{Superintendents of 2005}

South District

Legend

Superintendent (Schools Count)

$7(22) \bigcirc \quad 17(16) \bigcirc 52(15)$

$8(18) \bigcirc \quad 26(28) \bigcirc \quad 58(7)$

$16(1) \bigcirc 36(8) \bigcirc 67(12)$

68 (1) 
Map 4: Haifa District 2005

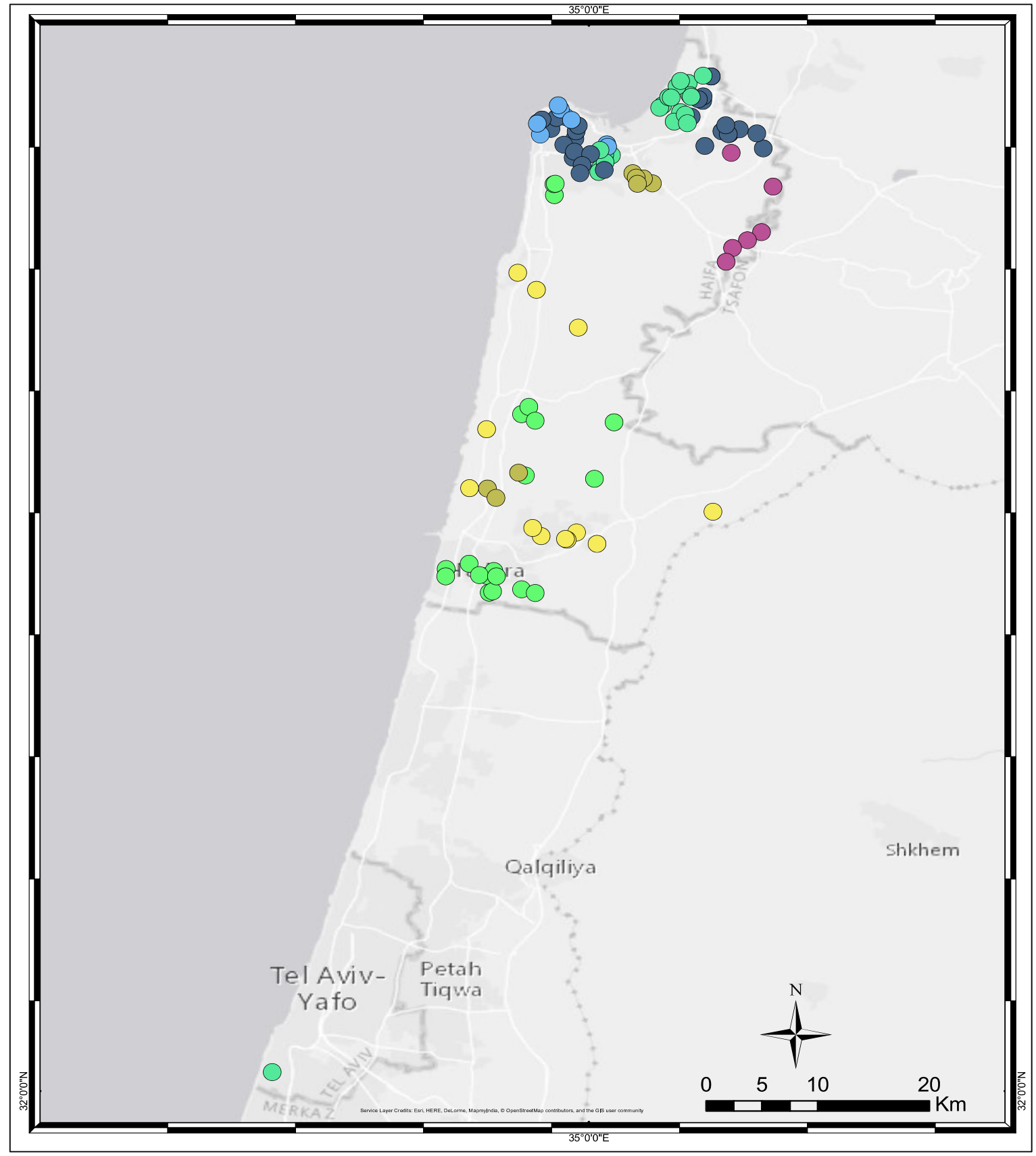

\section{Superintendents of $\mathbf{2 0 0 5}$}

Haifa District

$3(12) \bigcirc 42(27) \bigcirc 50(20)$

$\bigcirc 40(9) \bigcirc 46(8) \bigcirc 55(21)$ 
Map 5: Jerusalem District 2005

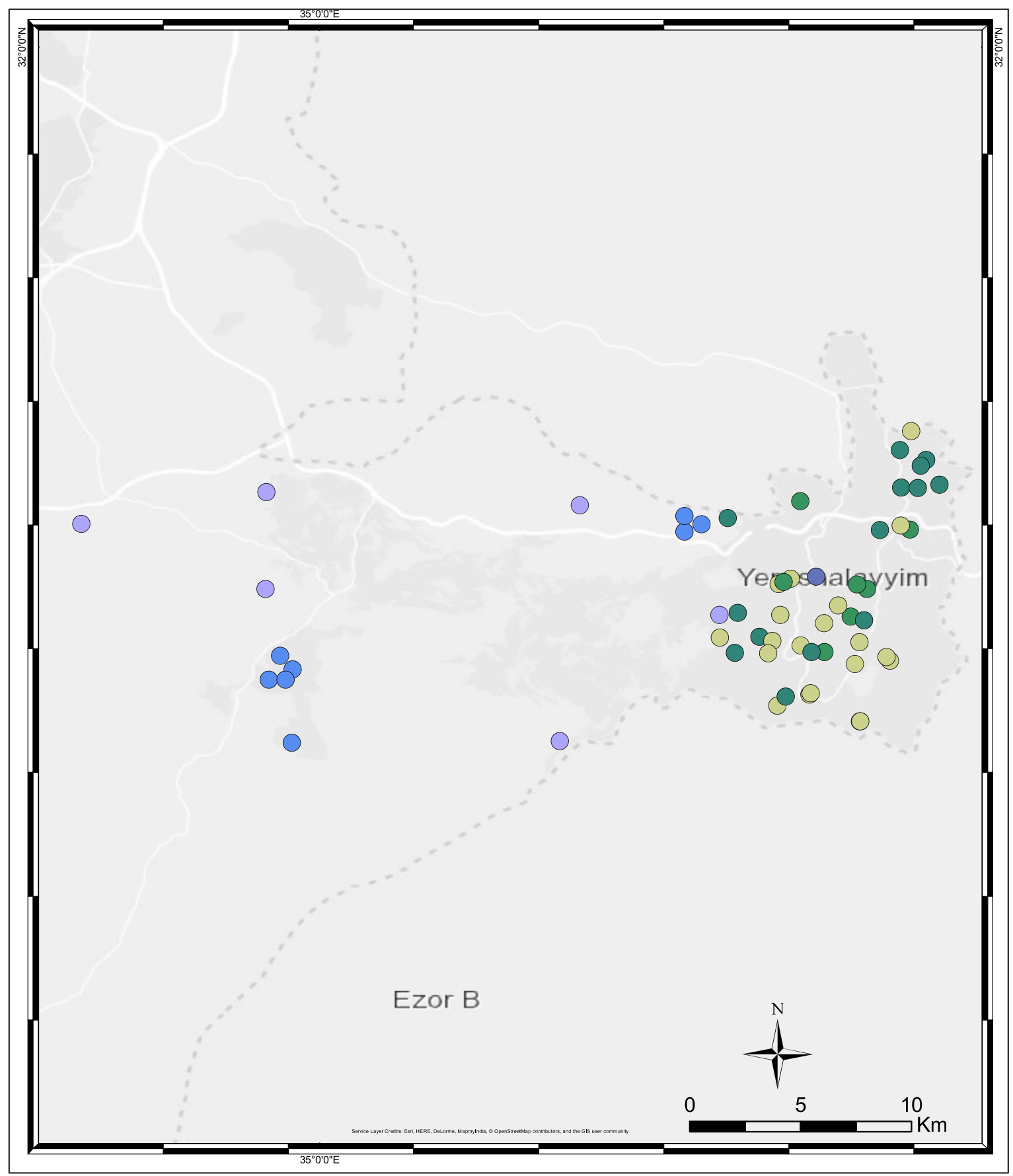

\section{Superintendents of $\mathbf{2 0 0 5}$} Jerusalem District

$4(1) \bigcirc 21(1) \bigcirc 39(19)$

$5(14) \bigcirc 34(6) \bigcirc 48(7)$

$68(8)$ 
Map 6: North District 2005

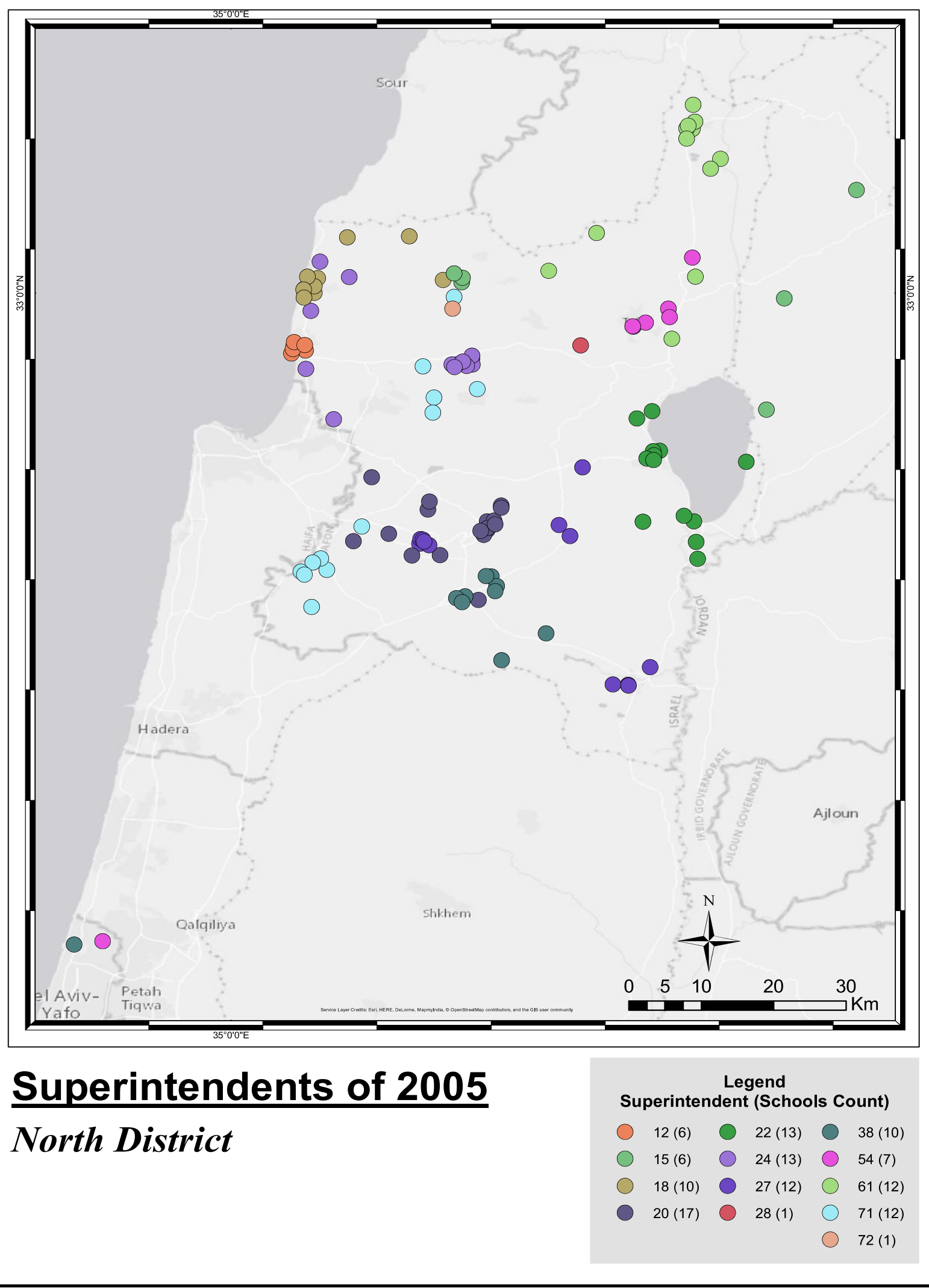


Map 7: North District 2005

Table A1: The Effect of Superintendent Value Added on Tests Z-Scores

\begin{tabular}{|c|c|c|c|c|}
\hline & \multicolumn{4}{|c|}{ Value Added Method I } \\
\hline & (1) & $(2)$ & (3) & (4) \\
\hline \multicolumn{5}{|l|}{ A. Full Sample } \\
\hline Schools' Sample Regressions & $\begin{array}{l}-0.003 \\
(0.025)\end{array}$ & $\begin{array}{c}-0.003 \\
(0.025)\end{array}$ & $\begin{array}{c}-0.012 \\
(0.016)\end{array}$ & $\begin{array}{c}0.036 \\
(0.020)\end{array}$ \\
\hline Students' Sample Regressions & $\begin{array}{c}0.002 \\
(0.025)\end{array}$ & $\begin{array}{c}0.002 \\
(0.025)\end{array}$ & $\begin{array}{c}-0.012 \\
(0.017)\end{array}$ & $\begin{array}{c}0.041 \\
(0.016)\end{array}$ \\
\hline \multicolumn{5}{|l|}{ B. Female Superintendents Sample } \\
\hline Schools' Sample Regressions & $\begin{array}{c}0.009 \\
(0.028)\end{array}$ & $\begin{array}{c}0.009 \\
(0.028)\end{array}$ & $\begin{array}{c}-0.009 \\
(0.019)\end{array}$ & $\begin{array}{c}0.049 \\
(0.022)\end{array}$ \\
\hline Students' Sample Regressions & $\begin{array}{c}0.019 \\
(0.028)\end{array}$ & $\begin{array}{c}0.019 \\
(0.028)\end{array}$ & $\begin{array}{c}-0.006 \\
(0.019)\end{array}$ & $\begin{array}{c}0.058 \\
(0.011)\end{array}$ \\
\hline \multicolumn{5}{|c|}{ C. Full Sample - By Parental Education (Student Level) } \\
\hline Below Median Father's Years of Schooling & $\begin{array}{c}-0.017 \\
(0.024)\end{array}$ & $\begin{array}{c}-0.017 \\
(0.024)\end{array}$ & $\begin{array}{c}-0.021 \\
(0.028)\end{array}$ & $\begin{array}{c}0.055 \\
(0.026)\end{array}$ \\
\hline Above Median Father's Years of Schooling & $\begin{array}{c}0.010 \\
(0.024)\end{array}$ & $\begin{array}{c}0.010 \\
(0.024)\end{array}$ & $\begin{array}{c}0.002 \\
(0.018)\end{array}$ & $\begin{array}{c}0.028 \\
(0.012)\end{array}$ \\
\hline Year FE & Yes & Yes & Yes & Yes \\
\hline Subject FE & No & Yes & Yes & Yes \\
\hline Schools" and Students' Characteristics & No & No & Yes & Yes \\
\hline School FE & No & No & No & Yes \\
\hline Number of Students & 9,295 & 9,295 & 9,236 & 9,236 \\
\hline Number of Schools & 75 & 75 & 75 & 75 \\
\hline Number of Superintendents & 29 & 29 & 29 & 29 \\
\hline \multicolumn{5}{|c|}{$\begin{array}{l}\text { Notes: Standard errors in parenthesis are clustered at the superintendent-by-year level. Schools characteristics include number of } \\
\text { classes, number of students and the number of schools included in a superintendent's cluster. Students' characteristics include gender, } \\
\text { ethnic origin, parents' education, number of siblings and immigrant status. All schools are in the jewish non-religious primary school } \\
\text { system. Sample includes stacked math, hebrew and english tests scores. Test scores and superintendents value added are standardized } \\
\text { with } 0 \text { mean and unit sd. The sample excludes the } 15 \text { schools that were reassigned as a single-school or two-schools cluster and their } \\
\text { reassignment showed no explicit spatial logic. } 7 \text { of these schools overlapped with the } 82 \text { schools in the analysis provided in Table } 6 \text {. }\end{array}$} \\
\hline
\end{tabular}




\begin{tabular}{|c|c|c|c|c|}
\hline & \multicolumn{4}{|c|}{ Value Added Method I } \\
\hline & (1) & (2) & (3) & (4) \\
\hline \multicolumn{5}{|l|}{ A. Full Sample } \\
\hline Schools' Sample Regressions & $\begin{array}{c}0.007 \\
(0.025)\end{array}$ & $\begin{array}{c}0.007 \\
(0.025)\end{array}$ & $\begin{array}{c}0.017 \\
(0.021)\end{array}$ & $\begin{array}{c}0.049 \\
(0.021)\end{array}$ \\
\hline Students' Sample Regressions & $\begin{array}{c}0.012 \\
(0.025)\end{array}$ & $\begin{array}{c}0.012 \\
(0.025)\end{array}$ & $\begin{array}{c}0.011 \\
(0.017)\end{array}$ & $\begin{array}{c}0.062 \\
(0.010)\end{array}$ \\
\hline \multicolumn{5}{|l|}{ B. Female Superintendents Sample } \\
\hline Schools' Sample Regressions & $\begin{array}{c}0.016 \\
(0.029)\end{array}$ & $\begin{array}{c}0.016 \\
(0.029)\end{array}$ & $\begin{array}{c}0.022 \\
(0.028)\end{array}$ & $\begin{array}{c}0.045 \\
(0.023)\end{array}$ \\
\hline Students' Sample Regressions & $\begin{array}{c}0.026 \\
(0.029)\end{array}$ & $\begin{array}{c}0.026 \\
(0.029)\end{array}$ & $\begin{array}{c}0.019 \\
(0.022)\end{array}$ & $\begin{array}{c}0.067 \\
(0.010)\end{array}$ \\
\hline \multicolumn{5}{|c|}{ C. Full Sample - By Parental Education (Student Level) } \\
\hline Below Median Father's Years of Schooling & $\begin{array}{c}-0.004 \\
(0.024)\end{array}$ & $\begin{array}{c}-0.004 \\
(0.025)\end{array}$ & $\begin{array}{c}-0.001 \\
(0.029)\end{array}$ & $\begin{array}{c}0.079 \\
(0.018)\end{array}$ \\
\hline Above Median Father's Years of Schooling & $\begin{array}{c}0.025 \\
(0.024)\end{array}$ & $\begin{array}{c}0.025 \\
(0.024)\end{array}$ & $\begin{array}{c}0.031 \\
(0.017)\end{array}$ & $\begin{array}{c}0.053 \\
(0.011)\end{array}$ \\
\hline Year FE & Yes & Yes & Yes & Yes \\
\hline Subject FE & No & Yes & Yes & Yes \\
\hline Schools' and Students' Characteristics & No & No & Yes & Yes \\
\hline School FE & No & No & No & Yes \\
\hline Number of Students & 8,222 & 8,222 & 8,164 & 8,164 \\
\hline Number of Schools & 66 & 66 & 66 & 66 \\
\hline Number of Superintendents & 23 & 23 & 23 & 23 \\
\hline \multicolumn{5}{|c|}{$\begin{array}{l}\text { Notes: Standard errors in parenthesis are clustered at the superintendent-by-year level. Schools characteristics include number of } \\
\text { classes, number of students and the number of schools included in a superintendent's cluster. Students' characteristics include gender, } \\
\text { ethnic origin, parents' education, number of siblings and immigrant status. All schools are in the jewish non-religious primary school } \\
\text { system. Sample includes stacked math, hebrew and english tests scores. Test scores and superintendents value added are standardized } \\
\text { with } 0 \text { mean and unit sd. The sample excludes the } 40 \text { schools that were reassigned as a single-school or two-schools cluster. } 16 \text { of these } \\
\text { schools overlapped with the } 82 \text { schools in the analysis provided in Table } 6 \text {. }\end{array}$} \\
\hline
\end{tabular}


Table A3: Violence and School Climate Regressions

\begin{tabular}{|c|c|c|c|c|c|}
\hline & \multicolumn{5}{|c|}{ Specification } \\
\hline & (1) & $(2)$ & (3) & (4) & $(5)$ \\
\hline \multicolumn{6}{|l|}{ A. Violence Index } \\
\hline Schools' Sample Regressions & $\begin{array}{c}-0.301 \\
(0.018)\end{array}$ & $\begin{array}{c}-0.301 \\
(0.018)\end{array}$ & $\begin{array}{c}-0.263 \\
(0.017)\end{array}$ & $\begin{array}{c}-0.237 \\
(0.015)\end{array}$ & $\begin{array}{c}-0.226 \\
(0.005)\end{array}$ \\
\hline Students' Sample Regressions & $\begin{array}{c}-0.708 \\
(0.101)\end{array}$ & $\begin{array}{c}-0.708 \\
(0.101)\end{array}$ & $\begin{array}{l}-0.529 \\
(0.112)\end{array}$ & $\begin{array}{c}-0.302 \\
(0.140)\end{array}$ & $\begin{array}{c}-0.278 \\
(0.050)\end{array}$ \\
\hline \multicolumn{6}{|l|}{ B. School Climate Index } \\
\hline Schools' Sample Regressions & $\begin{array}{c}-0.016 \\
(0.032)\end{array}$ & $\begin{array}{c}-0.016 \\
(0.032)\end{array}$ & $\begin{array}{c}0.009 \\
(0.029)\end{array}$ & $\begin{array}{c}0.070 \\
(0.047)\end{array}$ & $\begin{array}{c}0.023 \\
(0.011)\end{array}$ \\
\hline Students' Sample Regressions & $\begin{array}{c}-0.017 \\
(0.033)\end{array}$ & $\begin{array}{c}-0.017 \\
(0.033)\end{array}$ & $\begin{array}{c}0.005 \\
(0.030)\end{array}$ & $\begin{array}{c}0.086 \\
(0.043)\end{array}$ & $\begin{array}{c}0.020 \\
(0.012)\end{array}$ \\
\hline Year FE & Yes & Yes & Yes & Yes & Yes \\
\hline Subject FE & No & Yes & Yes & Yes & Yes \\
\hline Schools' and Students' Characteristics & No & No & Yes & Yes & Yes \\
\hline School FE & No & No & No & Yes & Yes \\
\hline Number of Schools & 82 & 82 & 82 & 82 & 719 \\
\hline Number of Students - Violence Index & 9,010 & 9,010 & 8,960 & 8,960 & 79,653 \\
\hline Number of Students - School Climate Index & 10,249 & 10,249 & 10,190 & 10,190 & 90,264 \\
\hline \multicolumn{6}{|c|}{$\begin{array}{l}\text { Notes : Standard errors in parenthesis are clustered at the school level. In Columns (1)-(4) the sample of } 82 \text { schools are the schools included in Table } \\
\text { 11. Column (5) includes all schools. Schools characteristics include number of classes, number of students and the number of schools included in a } \\
\text { superintendent's cluster. Students' characteristics include gender, ethnic origin, parents' education, number of siblings and immigrant status. Dependent } \\
\text { variable is tests scores in al specifications. All schools are in the jewish non-religious primary school system. Sample includes stacked math, hebrew } \\
\text { and english tests scores. School climate and violence indices are the averages of the questions presented in panels A and B accordingly of table } 11 \text {. The } \\
\text { violence index regressions include only students who answered the relevant questions in the student surveys. The school climate regressions include all } \\
\text { students, as the questions are from the principal survey and are on asked in the school level. Test scores and violence amd school climate indices are } \\
\text { standardized with } 0 \text { mean and unit sd. }\end{array}$} \\
\hline
\end{tabular}

